\title{
Article \\ Effect of Climate Change on the Growth of Endangered Scree Forests in Krkonoše National Park (Czech Republic)
}

\author{
Vojtěch Hájek $^{1}$, Stanislav Vacek ${ }^{1}$, Zdeněk Vacek ${ }^{1}$, Jan Cukor ${ }^{1,2, * \mathbb{D}}$, Václav Šimůnek ${ }^{1} \mathbb{D}$, Michaela Šimková ${ }^{1}$, \\ Anna Prokůpková ${ }^{1}$, Ivo Králíček ${ }^{3}$ and Daniel Bulušek ${ }^{1}$ \\ 1 Department of Silviculture, Faculty of Forestry and Wood Sciences, Czech University of Life Sciences Prague, \\ Kamýcká 129, 16500 Praha, Czech Republic; vhajek@fld.czu.cz (V.H.); vacekstanislav@fld.czu.cz (S.V.); \\ vacekz@fld.czu.cz (Z.V.); simunekv@fld.czu.cz (V.Š.); simkovamichaela@fld.czu.cz (M.Š.); \\ prokupkovaa@fld.czu.cz (A.P.); bulusek@fld.czu.cz (D.B.) \\ 2 Department of Game Management, Forestry and Game Management Research Institute, Strnady 136, \\ 25202 Jíloviště, Czech Republic \\ 3 Department of Biology, Faculty of Science, University of Hradec Králové, Rokitanského 62, \\ 50003 Hradec Králové, Czech Republic; ivo.kralicek@uhk.cz \\ * Correspondence: cukor@fld.czu.cz
}

check for updates

Citation: Hájek, V.; Vacek, S.; Vacek, Z.; Cukor, J.; Šimůnek, V.; Šimková, M.; Prokůpková, A.; Králíček, I.; Bulušek, D. Effect of Climate Change on the Growth of Endangered Scree Forests in Krkonoše National Park (Czech Republic). Forests 2021, 12, 1127. https://doi.org/10.3390/ f12081127

Academic Editor: Heli Peltola

Received: 30 July 2021

Accepted: 18 August 2021

Published: 22 August 2021

Publisher's Note: MDPI stays neutral with regard to jurisdictional claims in published maps and institutional affiliations.

Copyright: (c) 2021 by the authors. Licensee MDPI, Basel, Switzerland. This article is an open access article distributed under the terms and conditions of the Creative Commons Attribution (CC BY) license (https:/ / creativecommons.org/licenses/by/ $4.0 /)$.

\begin{abstract}
Scree forests with large numbers of protected plants and wildlife are seriously threatened by climate change due to more frequent drought episodes, which cause challenges for very stony, shallow soils. The effect of environmental factors on the radial growth of five tree species-European beech (Fagus sylvatica L.), Norway spruce (Picea abies (L.) Karst.), sycamore maple (Acer pseudoplatanus L.), European ash (Fraxinus excelsior L.), and mountain elm (Ulmus glabra Huds.) —was studied in the mixed stands (105-157 years) in the western Krkonoše Mountains (Czech Republic) concerning climate change. These are communities of maple to fir beechwoods (association Aceri-Fagetum sylvaticae and Luzulo-Abietetum albae) on ranker soils at the altitude 590-700 $\mathrm{m}$ a.s.l. Production, structure, and biodiversity were evaluated in seven permanent research plots and the relationships of the radial growth (150 cores) to climatic parameters (precipitation, temperature, and extreme conditions) and air pollution $\left(\mathrm{SO}_{2}, \mathrm{NO}_{\mathrm{X}}\right.$, ozone exposure). The stand volume reached $557-814 \mathrm{~m}^{3} \mathrm{ha}^{-1}$ with high production potential of spruce and ash. The radial growth of beech and spruce growing in relatively favorable habitat conditions (deeper soil profile and less skeletal soils) has increased by $16.6 \%-46.1 \%$ in the last 20 years. By contrast, for sycamore and ash growing in more extreme soil conditions, the radial growth decreased by $12.5 \%-14.6 \%$. However, growth variability increased $(12.7 \%-29.5 \%)$ for all tree species, as did the occurrence of negative pointer years (extremely low radial growth) in the last two decades. The most sensitive tree species to climate and air pollution were spruce and beech compared to the resilience of sycamore and ash. Spectral analysis recorded the largest cyclical fluctuations (especially the 12-year solar cycle) in spruce, while ash did not show any significant cycle processes. The limiting factors of growth were droughts with high temperatures in the vegetation period for spruce and late frosts for beech. According to the degree of extreme habitat conditions, individual tree species thus respond appropriately to advancing climate change, especially to an increase in the mean temperature (by $2.1^{\circ} \mathrm{C}$ ), unevenness in precipitation, and occurrence of extreme climate events in the last 60 years.
\end{abstract}

Keywords: mixed forests; dendrochronology; forest structure; biodiversity; rocky soils

\section{Introduction}

Forest management practices have a considerable impact on forest ecosystems, especially in the context of global climate change for adaptive and mitigation measures for increasing stability of forests [1,2]. Lack of precipitation and, as a result, more frequent and severe droughts will increasingly be a major risk to the growth, ecological stability, and vitality of forest ecosystems during global climate change [3,4]. Higher air temperatures, in 
addition to the current decrease in precipitation during the vegetation period in Central and Southern Europe in recent years, led to significant periods of summer drought, which often have serious consequences for growth processes in natural and commercial forests $[5,6]$. At the same time, it is often a matter of maintaining the bare existence of forests due to significantly increasing disturbances and the amount of salvage logging [7].

For the European Union, forests are important ecosystems filling other roles, specifically recreation and biodiversity, wood and non-wood (game, wild berries, mushrooms) resources, and carbon sequestration [8,9]. The Member States of the European Union are committed to maintain and protect their forests with a view to their sustainable development and the sustainable fulfillment of ecological (soil protection, protection of water resources, protection of landscape and nature), social and cultural (preservation of landscape and cultural heritage, recreational functions), and economic (renewable natural resource, source of employment and income) functions [10,11].

Mixed forest mountain ecosystems consisting mainly of Norway spruce (Picea abies (L.) Karst.), silver fir (Abies alba Mill.), and European beech (Fagus sylvatica L.) cover large areas of European mountains [12]. However, due to the long history of forest management in Europe, few primeval forest ecosystems in terms of their species, spatial, and age structure, have been preserved [13]. Nowadays, the stands are often formed by spruce monocultures with an even-aged structure [14], which are highly susceptible to disturbances due to changing climate $[15,16]$.

In many places, both research and silviculture are currently focused on the transformation of unmixed even-aged stands into mixed uneven-aged stands [17,18]. European beech plays an increasingly important role $[19,20]$ and the predicted warmer climate is assumed to be suitable even for silver fir, which grew well during the warmer, Middle Holocene period [21,22]. The growth of trees can then be positively influenced through the mixing of species within the stand [23,24], which has also been shown in beech [25], and partly in fir [26]. Other studies present the reduced sensitivity of woody plants in mixed stands to global climate change $[27,28]$.

Climate change, whether alone or synergistically with some non-climatic influences, directly affects the dynamics of mountain forest ecosystems [29,30]. Therefore, demographic changes may occur in forest ecosystems and the boundaries of particular tree species' distribution may also change [31,32]. However, the dynamics of forest ecosystems are also influenced by several other factors, such as forest management [33,34], mutual species and interspecies interactions [35,36], air pollution including ozone exposure, sulfur and nitrogen deposition [37-40], or introskeletal erosion [41]. Conversely, rising temperatures can prolong the length of the growing season and thus have an impact on both plant phenology and production $[42,43]$, which can compensate for the reduced production due to rising temperatures and drought stress [44,45].

Manifold interactions between factors that affect the growth of individual forest species and entire forests stands require complex investigation of various habitats with different species compositions. This will allow us to predict the impact of climate change on forest ecosystems in Central Europe more accurately [46] and optimize the management of given forest ecosystems accordingly $[47,48]$. Scree forests are among the specific stands that grow mainly on steep slopes with outcrops of rocks or with significant solifluction, in ravines, in the lower part of the slopes, and on the foot of the slopes with the accumulation of boulders or other rubble material [49]. Scree forests usually consist of small stand areas spread from the hills to mountainous locations; the upper limits reach altitudes of around 800-900 m [50,51]. Due to their hard-to-reach habitats, scree forests are one of our bestpreserved natural forests [34,52]. They are also among the most susceptible to intraskeletal erosion $[41,49]$ due to the increased mineralization of the holorganic horizons, in terms of their shallow soil profiles, even in conditions of global climate change. Conservation management of scree forests is often intervention-free, as they usually form small protected areas and protection forests [53]. 
In this study, we focused on mixed stands on shallow grounded rubble in the western Krkonoše Mountains. Here, the key factor is slope erosion caused by the often-unstable subsoil regarding the formation of the structure and dynamics of these scree forest stands. Forests in these conditions are often left to spontaneous development due to frequent disturbances, high biodiversity, and limited economic value, or their management is kept to a minimum $[54,55]$, such as in our area of interest. From the relatively specific conditions of mountain mixed forests on very stony, shallow soils, this paper should also contribute to the investigation of the endangered scree sites in the time of climate change. There is only partial knowledge about the structure and biodiversity of scree and ravine forests in specific environmental conditions, regarding the methods of their management [56,57].

The objective of this paper is to evaluate the effect of climate, air pollution, and other environmental factors on the growth of mixed scree forests dominated by European beech and Norway spruce with admixed sycamore maple (Acer pseudoplatanus L.), European ash (Fraxinus excelsior L.), and mountain elm (Ulmus glabra Huds.). The partial objectives were to determine (i) the production potential, stand structure (vertical, horizontal), and diversity (species, structural, total), (ii) dynamics of the radial growth of the five investigated tree species in relation to climate change, (iii) cycle processes of the radial growth of individual tree species using spectral analysis, and (iv) the effect of climate factors (temperature, precipitation, extremes, and changes), air pollution (concentrations of $\mathrm{SO}_{2}, \mathrm{NO}_{X}, \mathrm{AOT} 40 \mathrm{~F}$ ), and pests (insect, fungal pathogens) on the radial growth of individual tree species and the differences between them.

\section{Material and Methods}

\subsection{Study Site}

The area of interest is shallow grounded rubble in the western Krkonoše Mountains (west of Harrachov) on the slopes near the Jizera Valley at an altitude of 590-700 m (Figure 1). This area is part of the II and III nature protection zones of the Krkonoše National Park. These are richly structured mixed stands that belong to special-purpose forests and are left to spontaneous development, or are managed by the selection and shelterwood systems. Stands are most typically upland communities of maple and fir beechwoods, wherein their natural composition, European beech had $40 \%$, sycamore maple 20\%, silver fir 20\%, Norway spruce 10\%, and the rest consisted of European ash and mountain elm. However, silver fir almost became extinct there due to the synergism of the air pollution calamity (high concentrations of $\mathrm{SO}_{2}$ ) in the 1980s and 1990s and the attack of the silver fir woolly aphid (Dreyfusia nordmannianae) in the tree layer [58]. These are communities belonging mainly to the association Aceri-Fagetum sylvaticae, and also to the association Luzulo-Abietetum albae.

The mean annual temperature of the locality is $4.9^{\circ} \mathrm{C}\left(10.7^{\circ} \mathrm{C}\right.$ in the vegetation period $)$ and the annual total precipitation varies around $1200 \mathrm{~mm}(600 \mathrm{~mm}$ in the vegetation period), with maxima in July (Figure 1). The length of the vegetation period is 122 days and Lang's rain factor is 245 . The study area was qualified as a humid continental climate zone, characterized by warm to hot, humid summers and cold to severely cold winters (Dfb) as defined by the Köppen climate classification [59]. In terms of climate change, the average annual temperature has increased by $2.1^{\circ} \mathrm{C}$ over the last 58 years (1961-2019) and the total annual precipitation has decreased by $15 \mathrm{~mm}$, while fluctuations of monthly climatic data increased in both cases, especially in the case of precipitation. When comparing climatic extremes, 7 of the 10 warmest months were found in the last 15 years. Annual averages of $\mathrm{SO}_{2}$ concentrations during the air pollution disaster (in the 1970s and 1980s) ranged 120-410 $\mathrm{g} \mathrm{m} \mathrm{m}^{-3}$ and led to a significant decrease after 2000 to the current values of ca $4 \mu \mathrm{g} \mathrm{m}^{-3}$ [60]. The $\mathrm{NO}_{\mathrm{X}}$ concentration currently averages around $8 \mu \mathrm{g} \mathrm{m}^{-3}$, and ozone exposure (AOT40F) shows mean values of 27,000 $\mathrm{ppb} \mathrm{h}^{-1}$ [61]. 


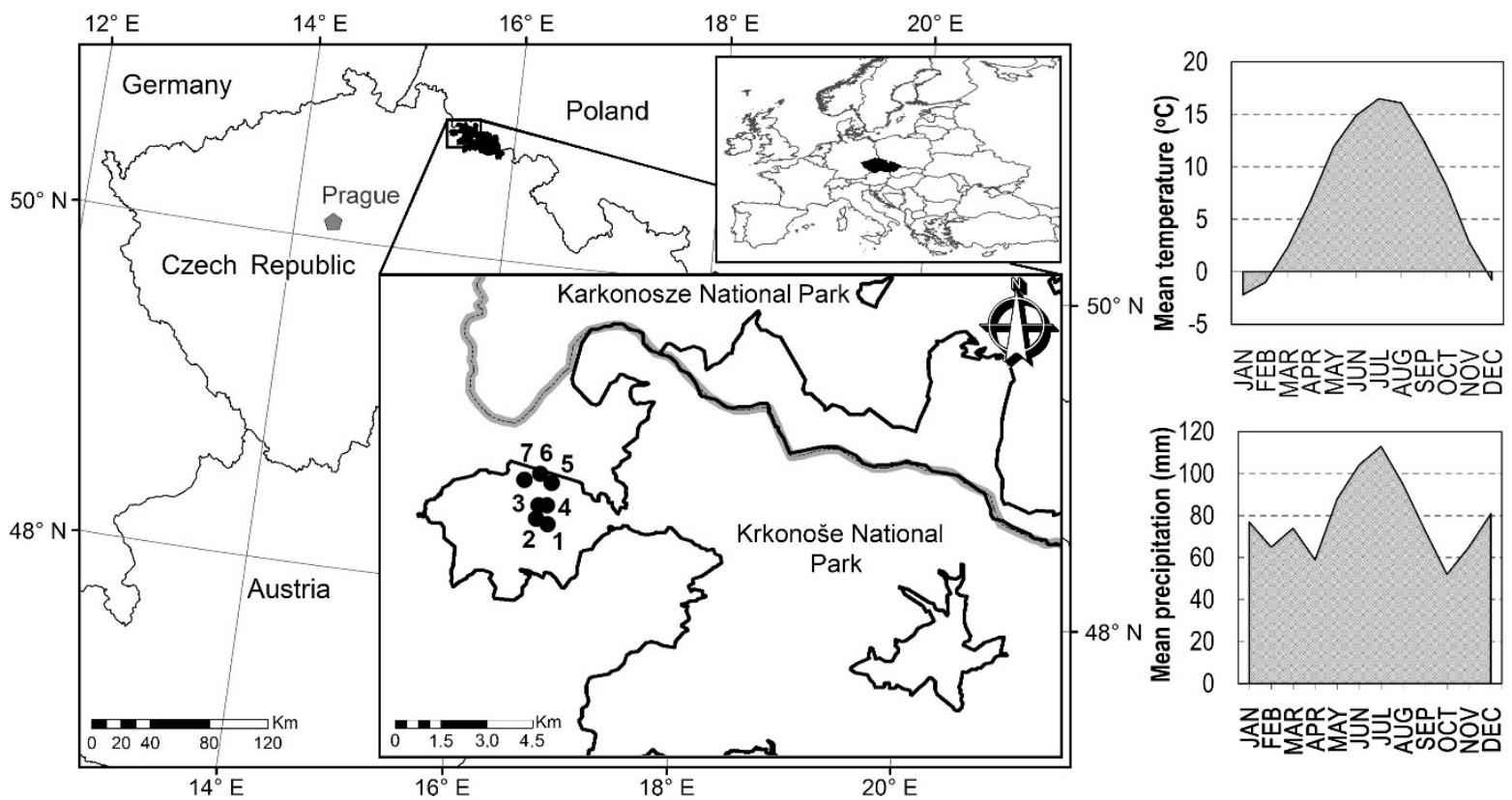

Figure 1. Location of permanent research plots 1-7 in mixed stands on scree sites in the western Krkonoše Mountains and the mean monthly climatic values in the period 1961-2019 (meteorological station Harrachov of Czech Hydrometeorological Institute); the map was made in ArcGIS 10 software (Esri).

The geological basis consists mainly of quartzites and phyllites. The predominant soil types are modal and cambic Rankers and ranker Cambisols. Depth and skeletality in scree forests are quite variable in a mosaic arrangement with numerous rocky outcrops. On very shallow soils (depth up to $30-40 \mathrm{~cm}$ ) and most skeletal soils (skeleton content over $70 \%$ ), there are mostly sycamore maple, ash, and elm. On relatively deeper (depth of soil profile over $50 \mathrm{~cm}$ ) and less skeletal soils (skeleton content up to 55\%), European beech and Norway spruce dominate.

A detailed overview of the basic site and stand data of permanent research plots (PRPs) is given in Table 1. The forest stands usually consist of two to three tree layers, with the age of the upper tree layer from 105 to 130 years. Given their management, the studied stands were divided into two groups. PRPs 1,2,5, and 7 have been left to develop spontaneously for more than 30 years, and PRPs 3, 4, and 6 are managed by near-natural methods. It is mainly the local introduction of silver fir, the proportion of which was reduced to a minimum during the air pollution disaster in the 1980s.

Table 1. Overview of basic site and stand characteristics of permanent research plots 1-7 in the western Krkonoše Mountains in 2020 .

\begin{tabular}{|c|c|c|c|c|c|c|c|c|c|c|}
\hline PRP & GPS & $\begin{array}{l}\text { Altitude } \\
\text { (m) }\end{array}$ & Exposition & $\begin{array}{c}\text { Slope } \\
\left({ }^{\circ}\right)\end{array}$ & $\begin{array}{l}\text { Forest Site } \\
\text { Type }\end{array}$ & Geology & Soils & Species & $\begin{array}{c}\text { Age of Tree } \\
\text { Layers } \\
\text { (Years) }\end{array}$ & $\begin{array}{c}\text { Stand } \\
\text { Volume } \\
\left(\mathrm{m}^{3} \mathrm{ha}^{-1}\right)\end{array}$ \\
\hline 1 & $\begin{array}{l}50^{\circ} 44^{\prime} 57^{\prime \prime} \mathrm{N}, \\
15^{\circ} 24^{\prime} 43^{\prime \prime} \mathrm{E}\end{array}$ & 600 & SW & 15 & $\begin{array}{l}\text { Acereto-Fagetum } \\
\text { lapidosum }\end{array}$ & phyllite & $\begin{array}{l}\text { cambic } \\
\text { Rankers }\end{array}$ & $\mathrm{Pa}, \mathrm{Fs}, \mathrm{Ap}, \mathrm{Ug}$ & $151 / 18$ & 336 \\
\hline 2 & $\begin{array}{l}50^{\circ} 44^{\prime} 59^{\prime \prime} \mathrm{N} \\
15^{\circ} 24^{\prime} 37^{\prime \prime} \mathrm{E}\end{array}$ & 590 & SW & 17 & $\begin{array}{l}\text { Acereto-Fagetum } \\
\text { lapidosum }\end{array}$ & phyllite & $\begin{array}{l}\text { cambic } \\
\text { Rankers }\end{array}$ & $\mathrm{Pa}, \mathrm{Fs}, \mathrm{Ap}, \mathrm{Ug}, \mathrm{Aa}$ & $121 / 18$ & 489 \\
\hline 3 & $\begin{array}{l}50^{\circ} 45^{\prime} 03^{\prime \prime} \mathrm{N} \\
15^{\circ} 24^{\prime} 40^{\prime \prime} \mathrm{E}\end{array}$ & 620 & SW & 13 & $\begin{array}{l}\text { Acereto-Fagetum } \\
\text { lapidosum }\end{array}$ & phyllite & $\begin{array}{c}\text { ranker } \\
\text { Cambisols }\end{array}$ & $\mathrm{Pa}, \mathrm{Fs}, \mathrm{Ap}, \mathrm{Aa}$ & $107 / 17$ & 394 \\
\hline 4 & $\begin{array}{l}50^{\circ} 45^{\prime} 03^{\prime \prime} \mathrm{N} \\
15^{\circ} 24^{\prime} 42^{\prime \prime} \mathrm{E}\end{array}$ & 610 & SW & 15 & $\begin{array}{l}\text { Acereto-Fagetum } \\
\text { lapidosum }\end{array}$ & phyllite & $\begin{array}{l}\text { modal } \\
\text { Rankers }\end{array}$ & $\mathrm{Pa}, \mathrm{Fs}, \mathrm{Ap}, \mathrm{Fe}$ & $105 / 7$ & 377 \\
\hline 5 & $\begin{array}{c}50^{\circ} 45^{\prime} 37^{\prime \prime} \mathrm{N} \\
15^{\circ} 24^{\prime} 40^{\prime \prime} \mathrm{E}\end{array}$ & 680 & SW & 13 & $\begin{array}{l}\text { Piceeto-Fagetum } \\
\text { lapidosum } \\
\text { acidophilum }\end{array}$ & quartzite & $\begin{array}{l}\text { cambic } \\
\text { Rankers }\end{array}$ & $\mathrm{Pa}, \mathrm{Fs}, \mathrm{Ap}$ & $128 / 39 / 19$ & 419 \\
\hline 6 & $\begin{array}{l}50^{\circ} 45^{\prime} 40^{\prime \prime} \mathrm{N} \\
15^{\circ} 24^{\prime} 34^{\prime \prime} \mathrm{E}\end{array}$ & 700 & SW & 32 & $\begin{array}{l}\text { Piceeto-Fagetum } \\
\text { saxatile }\end{array}$ & quartzite & $\begin{array}{c}\text { modal } \\
\text { Rankers }\end{array}$ & $\mathrm{Pa}, \mathrm{Fs}, \mathrm{Ap}, \mathrm{Fe}$ & $130 / 24$ & 484 \\
\hline 7 & $\begin{array}{c}50^{\circ} 45^{\prime} 38^{\prime \prime} \mathrm{N} \\
15^{\circ} 24^{\prime} 25^{\prime \prime} \mathrm{E}\end{array}$ & 650 & W & 15 & $\begin{array}{l}\text { Piceeto-Fagetum } \\
\text { lapidosum } \\
\text { acidophilum }\end{array}$ & quartzite & $\begin{array}{c}\text { ranker } \\
\text { Cambisols }\end{array}$ & $\mathrm{Pa}, \mathrm{Fs}, \mathrm{Ap}, \mathrm{Ug}$ & $136 / 19$ & 359 \\
\hline
\end{tabular}

Notes: Pa-Norway spruce (Picea abies (L.) Karst.), Fs—European beech (Fagus sylvatica L.), Ap—sycamore maple (Acer pseudoplatanus L.), Ug—mountain elm (Ulmus glabra Huds.), Fe-European ash (Fraxinus excelsior L.), Aa—silver fir (Abies alba Mill.). 


\subsection{Data Collection}

FieldMap technology (IFER-Monitoring and Mapping Solutions Ltd.) was used to determine the structure of the tree layer of forest stands on seven PRPs with a size of $50 \times 50 \mathrm{~m}(0.25 \mathrm{ha})$ in 2020 . The position of all individuals of the tree layer with a diameter at breast height over $4 \mathrm{~cm}$ was measured. The diameter limit was determined according to Slanař et al. [18], Bulušek et al. [36], Král et al. [60], and other researches, where individuals under $4 \mathrm{~cm}$ are included to natural regeneration. Tree heights, heights of the live crown base, and crown projection area were also measured in the tree layer, in at least 4 directions perpendicular to each other. Diameters of the tree layer were measured by a Mantax Blue metal caliper (Haglöf, Sweden) with an accuracy to $1 \mathrm{~mm}$, and the heights were measured using a Vertex laser hypsometer (Haglöf, Sweden) with an accuracy to $0.1 \mathrm{~m}$.

For dendrochronological analysis of the samples, increment cores were taken using a Pressler auger perpendicular to the axis of the trunk at a height of $1.3 \mathrm{~m}$ above the ground. Thirty core samples were randomly (RNG Excel function) taken from healthy predominant and dominant trees (according to Kraft/1884/classification) of the five following tree species: European beech, Norway spruce, sycamore maple, European ash, and mountain elm. A total of 150 cores were taken for dendrochronology (135 cores were used for analysis). Increment cores were measured with an Olympus microscope with a LINTAB measuring table (Rinntech, Heidelberg, Germany). The measurement was performed with an accuracy of $0.01 \mathrm{~mm}$, and TSAP-Win software (Rinntech, Heidelberg, Germany) was used to record the increment cores. Measurements were made from the bark towards the core perpendicular to the center of the trunk so that each annual ring was measured perpendicular to the trunk axis.

Data sets from meteorological stations and air pollution monitoring stations were used to derive stress factors related to climate and air pollution. Available data from the Desná-Souš station (772 m above sea level; GPS $50^{\circ} 47^{\prime} 23^{\prime \prime} \mathrm{N}, 15^{\circ} 19^{\prime} 9^{\prime \prime} \mathrm{E}$ ), which is approximately $6 \mathrm{~km}$ away from the monitored PRPs, was used to analyze the air pollution situation according to $\mathrm{SO}_{2}(1970-2012)$ and $\mathrm{NO}_{\mathrm{x}}$ (1994-2019) concentrations, and AOT40F (1993-2019). Mean and maximum values of concentrations in $\mu \mathrm{g} \mathrm{m}^{-3}$ and $\mathrm{ppb} \mathrm{h}^{-1}$ and their 95 quantiles were used for evaluation. Climate behavior in terms of temperature and precipitation ratios was evaluated based on the data from the meteorological station Harrachov from the years 1961-2019 (690 m above sea level; GPS 50 $46^{\prime} 29^{\prime \prime} \mathrm{N}, 15^{\circ} 25^{\prime} 39^{\prime \prime}$ E, located about $3 \mathrm{~km}$ from the monitored PRPs). The development of temperature and precipitation conditions was studied on the basis of data on mean annual temperature, temperature in the vegetation period, temperature outside the vegetation period, temperature in individual months, temperature variability, minima and maxima, and an annual sum of precipitation, precipitation in the vegetation period, precipitation outside the vegetation period, precipitation in individual months, precipitation variability, minima, and maxima. The study area have been long-term monitored by various specialists in the fields, and damage by other climatic factors (wind, late frost) and pests (bark beetles, Cryptococcus fagisuga, Ophiostoma ulmi, Rhytisma acerinum) has been recorded.

\subsection{Data Analysis}

The basic structure, biodiversity, and production characteristics of the tree layer were evaluated by the SIBYLA 5.1. software [62]. The stand volume was calculated according to Petráš and Pajtík [63]. The relative stand density index (SDI) [64], the crown closure (CC) [65], and the crown projection area (CPA) were observed for each plot. The maximum SDI value was derived from the model of the yield tables [66]. Slenderness coefficient (height to diameter ratio-HDR) was evaluated as an indicator of static stand stability $[67,68]$ according to the following range: excellent $(\mathrm{HDR}<82)$, good $(83-92)$, satisfactory (93-101), and dissatisfactory (>102) [69]. Species diversity was evaluated by species richness [70], species heterogeneity [71], and species evenness [72]. In terms of structure, horizontal structure [73], Arten-profile index [74], vertical diversity, crown differentiation [75], and diameter and height differentiation [76] were calculated. Moreover, 
total stand diversity [75] was determined based on tree species diversity, diversity of vertical structure, diversity of tree spatial distribution, and diversity of crown differentiation (Table 2). For calculation of horizontal structure, the software PointPro 2.1 (CULS Prague, Zahradník) was used. The Monte Carlo technique was used to simulate random data sets. For each investigated plot, 4000 simulations of the Poisson forest with the same stand density as the investigated stand were performed. When the value of the aggregation index exceeds the upper or lower limit of the random distribution interval (at significance 0.05), the horizontal structure of trees is regular or aggregated [77].

Table 2. Overview of indices describing the stand diversity and their common interpretation.

\begin{tabular}{|c|c|c|c|c|}
\hline Criterion & Quantifiers & Label & Reference & Evaluation \\
\hline \multirow{3}{*}{ Species diversity } & Richness & $D(\mathrm{Mi})$ & [70] & \multirow{9}{*}{$\begin{array}{c}\text { minimum } D=0 \text {, higher } D=\text { higher values } \\
\text { minimum } H^{\prime}=0 \text {, higher } H^{\prime}=\text { higher values } \\
\text { range } 0-1 ; \text { minimum } E=0 \text {, maximum } E=1 \\
\text { mean value } R=1 \text {; aggregation } R<1 \text {; regularity } \\
R>1 \\
\text { range } 0-1 \text {; balanced vertical structure } A<0.3 \text {; } \\
\text { selection forest } A>0.9 \\
\text { low } S<0.3 \text {, medium } S=0.3-0.5 \text {, high } \\
\mathrm{S}=0.5-0.7 \text {, very high diversity } S>0.7 \\
\text { range } 0-1 \text {; low } T M<0.3 \text {; very high } \\
\text { differentiation } T M>0.7 \\
\text { low } K<1.0 \text {, medium } K=1.0-1.5 \text {, high } \\
K=1.5-2.0 \text {, very high differentiation } K>2.0 \\
\text { monotonous structure } B<4 \text {; uneven structure } \\
B=6-8 \text {; very diverse structure } B>9\end{array}$} \\
\hline & Heterogeneity & $H^{\prime}(\mathrm{Si})$ & [71] & \\
\hline & Evenness & $E(\mathrm{Pii})$ & [72] & \\
\hline Horizontal structure & Aggregation index & $R(\mathrm{C} \& \mathrm{Ei})$ & [73] & \\
\hline Vertical structure & Arten-profile index & $A$ (Pri) & [74] & \\
\hline \multirow{3}{*}{$\begin{array}{c}\text { Structure } \\
\text { differentiation }\end{array}$} & Vertical div. & $S(\mathrm{~J} \& \mathrm{Di})$ & [75] & \\
\hline & $\begin{array}{l}\text { Diameter dif. } \\
\text { Height dif. }\end{array}$ & $\begin{array}{l}T M_{d}(\mathrm{Fi}) \\
T M_{h}(\mathrm{Fi})\end{array}$ & [76] & \\
\hline & Crown dif. & $K(\mathrm{~J} \& \mathrm{Di})$ & [75] & \\
\hline Complex diversity & Stand diversity & $B(\mathrm{~J} \& \mathrm{Di})$ & [75] & \\
\hline
\end{tabular}

Cross-dating the increment cores was performed in the CDendro program so that the cross-correlation index was CC $>25$ for each sample [78]. Dendrochronological data were processed using R software [79] using the "dplr" package [80-82]. The detrending of each tree was performed negatively by exponential detrending with an interleaved spline of $1 / 3$ of the age of each tree. This detrending removes the age trend while maintaining low-frequency climate signals [83]. The EPS (expressed population signal) was calculated for detrended data. The EPS represents the reliability of a chronology as a fraction of the joint variance of the theoretical infinite tree population. The limit for using the data for comparison against climatic data was a significant EPS limit so that EPS $>0.85$ [80]. The SNR (signal to noise ratio), which represents the signal strength of chronology, and R-bar (inter-series correlations) [84] were also calculated. The first-order autocorrelation (Ar1) was also carried out. The EPS, SNR, R-bar, Ar1 were calculated by the instructions to "dplr" [80] based on common dendrochronological theories [84,85].

The pointer years analysis of the relative growth change was carried out [86] to determine changes in tree-rings. The pointer year is created by normalizing the tree-ring series in a moving window with each year placed as a central point. The pointer years reflect the number of standard deviations from the local mean of the average ring width of the previous four years. The pointer years identify event years where pointer year $>0.75$ standard deviation of the previous four years. The threshold on the percentage of trees in a negative or positive event year was used for better clarity [87]. The pointer years or mean annual growth deviation (in percentage) are distinguished for the most common event-year class.

Spectral analyses for the detrended radial increment of each studied tree species were performed with Statistica 13 software (StatSoft, Tulsa, OK, USA). The calculation was performed with the "Single Fourier (Spectral) Analysis" function, using the output "Periodogram" plot by Period".

The average ring series from individual tree species were correlated with climatic data (precipitation, temperature) and air pollution data ( $\mathrm{AOT} 40 \mathrm{~F}, \mathrm{SO}_{2}$, and $\mathrm{NO}_{\mathrm{x}}$ concentrations) 
in Statistica 13 software (StatSoft, Tulsa, OK, USA). DendroClim software [88] was used to model the radial increment depending on the monthly climatic characteristics.

Unconstrained principal component analysis (PCA) in Canoco 5 [89] was used to analyze the relationships between climate factors, air pollution load, and the radial growth of tree species. Data were log-transformed, centered, and standardized before the analysis. The results of PCA were exported into the form of an ordination diagram. The situation map was made in ArcGIS 10 software (Esri, West Redlands, CA, USA).

\section{Results}

\subsection{Stand Structure and Production}

The number of live trees in the tree layer in 2020 ranged between 260 and 480 trees ha $^{-1}$ (on average 328 trees ha ${ }^{-1}$ ); for stands left to spontaneous development, the average was 296 trees ha $^{-1}$, and for managed stands, 372 trees ha $^{-1}$ (Table 3). The stand density index ranged from 0.60 to 0.81 (on average 0.68 ). The canopy closure ranged from 76.6 to $97.4 \%$. Considering the rather extreme habitat, the stand production capacity was at a relatively high level. The average basal area reached $46.2 \mathrm{~m}^{2} \mathrm{ha}^{-1}$ for stands left to spontaneous development and $45.8 \mathrm{~m}^{2} \mathrm{ha}^{-1}$ for managed stands. The highest stand volume was $814 \mathrm{~m}^{3} \mathrm{ha}^{-1}$ on PRP 7, and the smallest was $597 \mathrm{~m}^{3} \mathrm{ha}^{-1}$ on PRP 3, where overhead release felling was performed. In stands left to spontaneous development, the average stand volume was $730 \mathrm{~m}^{3} \mathrm{ha}^{-1}$, and in managed stands, it was lower by $17.9 \%\left(599 \mathrm{~m}^{3} \mathrm{ha}^{-1}\right)$. The mean annual increment varies in the range of 4.28-6.06 $\mathrm{m}^{3} \mathrm{ha}^{-1} \mathrm{yr}^{-1}$; for unmanaged stands, it was $5.78 \mathrm{~m}^{3} \mathrm{ha}^{-1} \mathrm{yr}^{-1}$, and in managed stands, $4.81 \mathrm{~m}^{3} \mathrm{ha}^{-1} \mathrm{yr}^{-1}$. The slenderness ratio-within the limits for the given habitat and stand conditions-showed excellent static stability of these stands (HDR 62.6-74.2).

Table 3. Structural characteristics of tree layer on permanent research plots 1-7 in the western Krkonoše Mountains in 2020.

\begin{tabular}{|c|c|c|c|c|c|c|c|c|c|c|c|c|c|}
\hline PRP & Age & DBH & h & f & $\mathbf{v}$ & $\mathbf{N}$ & BA & V & HDR & MAI & $\mathrm{CC}$ & CPA & SDI \\
\hline & (yr) & $(\mathrm{cm})$ & $(\mathrm{m})$ & & $\left(\mathrm{m}^{3}\right)$ & $\left(\right.$ trees ha $\left.^{-1}\right)$ & $\left(\mathrm{m}^{2} \mathrm{ha}^{-1}\right)$ & $\left(\mathrm{m}^{3} \mathrm{ha}^{-1}\right)$ & & $\left(\mathrm{m}^{3} \mathrm{ha}^{-1} \mathrm{yr}^{-1}\right)$ & $(\%)$ & $\left(\right.$ ha ha ${ }^{-1}$ ) & \\
\hline 1 & 151 & 43.7 & 32.3 & 0.516 & 2.504 & 276 & 41.4 & 691 & 74.2 & 4.58 & 84.0 & 3.18 & 0.63 \\
\hline 2 & 121 & 39.7 & 28.1 & 0.498 & 1.860 & 344 & 42.6 & 640 & 71.8 & 5.29 & 88.9 & 3.43 & 0.68 \\
\hline 3 & 107 & 41.5 & 24.8 & 0.524 & 1.755 & 340 & 45.8 & 597 & 60.4 & 5.58 & 76.6 & 2.16 & 0.60 \\
\hline 4 & 105 & 36.0 & 24.3 & 0.541 & 1.338 & 480 & 48.9 & 642 & 62.6 & 4.57 & 97.4 & 2.51 & 0.80 \\
\hline 5 & 128 & 46.0 & 33.1 & 0.464 & 2.554 & 304 & 50.5 & 776 & 72.0 & 6.06 & 92.1 & 3.31 & 0.70 \\
\hline 6 & 130 & 43.0 & 21.8 & 0.594 & 1.881 & 296 & 42.8 & 557 & 66.1 & 4.28 & 95.6 & 2.23 & 0.66 \\
\hline 7 & 136 & 49.6 & 33.2 & 0.488 & 3.132 & 260 & 50.1 & 814 & 71.3 & 5.99 & 94.0 & 3.12 & 0.71 \\
\hline
\end{tabular}

Notes: Age - mean stand age, DBH—mean quadratic diameter at breast height, $\mathrm{h}$-mean tree height, $\mathrm{f}$ - form factor, $\mathrm{v}-\mathrm{mean}$ tree volume, $\mathrm{N}$-number of trees per hectare, BA-basal area, V—stand volume, HDR-height to diameter ratio (slenderness quotient), MAI-mean annual increment, $\mathrm{CC}$ - canopy closure, CPA—crown projection area, SDI—stand density index.

The diameter distribution and relationship between $\mathrm{DBH}$ and height of the tree layer are clearly shown in Figure 2. Three to four stories were measured in stands left to spontaneous development and two to three levels in managed stands. The tree layers of all PRPs were dominated by beech followed by spruce and maple. On PRP 1, 2, and 7, elm was admixed, while it was ash on PRP 4 and 6. Fir was interspersed only on PRP 2 and 3. All tree species except the fir are represented in all stories. Only the fir is represented in the lowest story. The diameter distribution on the left side is closer to the shape of the Gaussian curve with the highest frequency of trees in diameter class $48-56 \mathrm{~cm}$. The highest tree was observed in the case of spruce $(42.6 \mathrm{~m})$ followed by beech $(41.0 \mathrm{~m})$, while it was lowest in the case of sycamore $(33.0 \mathrm{~m})$ and ash $(33.7 \mathrm{~m})$. 

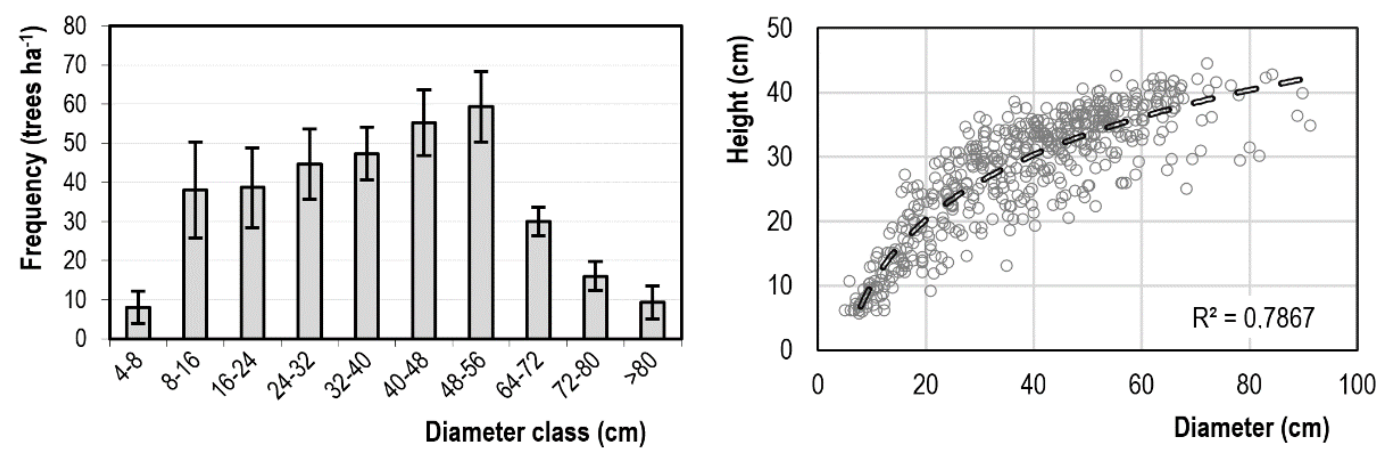

Figure 2. Frequency of diameter classes of tree layer and relationship between diameter at breast height and tree height summary for all permanent research plots 1-7 in the western Krkonoše Mountains in 2020; error bars indicate standard error and $\mathrm{R}^{2}$ coefficient of determination.

\subsection{Tree Layer Biodiversity}

In terms of species diversity, the species richness of the tree layer was low to medium, as was species heterogeneity (Table 4). The species evenness ranged from medium to very high. The horizontal structure of the tree layer was significantly $(\alpha=0.05)$ aggregated on PRP 1 and 7, on other PRPs, the spatial pattern was random with a prevailing tendency to aggregated distribution of trees. According to the standardized $A$ index, the vertical structure of the tree layer was moderately diversified on most PRPs, only on PRP 6 was it strongly diversified. However, the diversity of the vertical structure according to $B$ index was high on all PRPs except PRP 2, where it was medium. The diameter differentiation was medium on all PRPs, and the height differentiation was low to medium. Crown differentiation was medium on all PRPs. In terms of the total diversity of the tree layer, uneven stand structure was observed on all PRPs, while diversity was higher by $1.3 \%$ $(B=6.555)$ in unmanaged compared to managed stands $(B=6.469)$.

Table 4. Indices of tree layer biodiversity on permanent research plots 1-7 in the western Krkonoše Mountains in 2020.

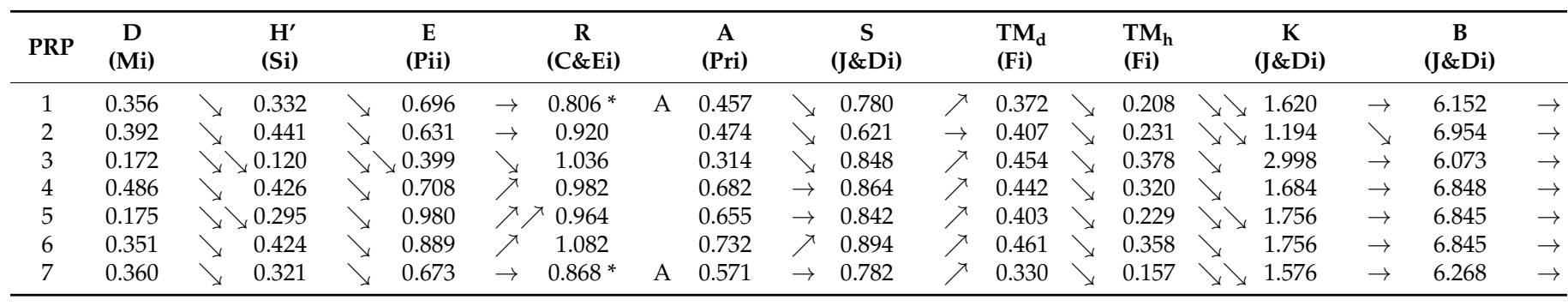

Notes: D-species richness, $\mathrm{H}^{\prime}$-species heterogeneity, E-species evenness, $\mathrm{R}$-aggregation index, A-Arten-profile index, $\mathrm{S}$-vertical diversity, $\mathrm{TM}_{\mathrm{d}}$-index of diameter differentiation, $\mathrm{TM}_{\mathrm{h}}$-index of height differentiation, $\mathrm{K}$-crown differentiation, $\mathrm{B}$ - stand diversity index.

* statistically significant aggregated spatial pattern $(\alpha=0.05)$ for horizontal structure (R index), arrows: $\searrow \searrow$ low, $\searrow-$ lo w-medium, $\rightarrow$-medium, $\nearrow$-high, $\nearrow \nearrow$-very high value of diversity.

\subsection{Dynamics of Radial Growth}

The dendrochronological analyses show that Norway spruce $(\mathrm{RW}=2.41 \mathrm{~mm})$ reached the largest average diameter increment (Table 5). Tree species such as mountain elm, European ash, and sycamore maple had similar RW ranging from 1.96 to $2.09 \mathrm{~mm}$. The lowest diameter increment was recorded for European beech $(\mathrm{RW}=1.43 \mathrm{~mm})$. Comparing the period 2010-2019 to 1990-2009, radial growth increased in spruce by $46.1 \%$ and in beech by $20.6 \%$, while it decreased in ash by $14.9 \%$ and sycamore by $12.5 \%$ (no changes in the case of elm- $0.1 \%$ ). On the other hand, the annual variability in growth increased in all tree species, from $12.7 \%$ (in elm) to $29.5 \%$ (in ash) in the last 20 years. The oldest tree recorded in the studied area was a 152-year-old beech. Other tree species showed a maximum age from 120 to 145 years. Spruce reached higher autocorrelation values $(\operatorname{Ar} 1=0.76)$ than European beech $(\mathrm{Ar} 1=0.68)$. However, other admixed and less represented tree species 
(elm, ash, and sycamore) showed higher autocorrelations (Ar1 $=0.80-0.85)$. The values of the EPS results were sufficiently significant for spruce $(\mathrm{EPS}=0.95)$, beech $(\mathrm{EPS}=0.89)$, elm $(E P S=0.86)$, and ash $(E P S=0.87)$; recording EPS values higher than 0.85 . Sycamore maple showed the lowest value of EPS $(E P S=0.65)$ due to the lower number of used core samples.

Table 5. Overview of basic dendrochronological characteristics of tree species in the western Krkonoše Mountains in 2020.

\begin{tabular}{|c|c|c|c|c|c|c|c|c|}
\hline Species & $\begin{array}{c}\text { No. } \\
\text { (Cores) }\end{array}$ & $\begin{array}{c}\text { Age Min.-Max. } \\
\text { (yr) }\end{array}$ & $\begin{array}{c}\text { Mean RW } \\
(\mathrm{mm})\end{array}$ & $\begin{array}{c}\text { Min.-Max. RW } \\
(\mathrm{mm})\end{array}$ & SD & Ar1 & R-Bar & EPS \\
\hline Norway spruce & 27 & $85-135$ & 2.41 & $1.774-3.354$ & 1.27 & 0.76 & 0.46 & 0.95 \\
\hline European beech & 30 & $104-152$ & 1.43 & $1.065-2.463$ & 0.70 & 0.68 & 0.27 & 0.89 \\
\hline Mountain elm & 26 & 84-145 & 1.98 & $1.124-3.264$ & 1.28 & 0.85 & 0.24 & 0.86 \\
\hline European ash & 28 & $84-120$ & 2.09 & $1.497-3.623$ & 1.11 & 0.80 & 0.26 & 0.87 \\
\hline Sycamore maple & 24 & 80-134 & 1.96 & $1.173-2.530$ & 1.17 & 0.82 & 0.19 & 0.65 \\
\hline
\end{tabular}

Notes: No.- number of used core samples, Age-age of trees in diameter at breast height (130 cm), RW—tree ring width, SD—standard deviation, Ar1 - first-order autocorrelation, R-bar-inter-series correlation, EPS—expressed population signal.

The standardized annual ring curves showed different courses of growth in tree species from 1960 to 2019 (Figure 3). The largest fluctuations in the radial growth were in spruce and elm, followed by beech compared to low variability in growth as in the case of ash and sycamore. In spruce, the negative decrease of the radial growth in 1972 was caused by a lack of precipitation (62\% of precipitation of the long-term average 1961-2019) until 1974. In the period from 1970 to 1985, the growth of spruce was negatively affected by air pollution load. The effect of air pollution in synergism with winter drying in spruce was most prominent in the years 1980-1984. In early spring 1995, due to a thick layer of wet snow, some of the spruce trees were damaged by top breaks, and the following year, 1996, was very cold (75\% of the average), which influenced the decrease in the radial growth. Long-term droughts in the vegetation period were recorded in 2006 (47\% of the average in June and July). The significantly declining radial growth in 2018-2019 was due to a substantially reduced sum of precipitation (74\% of the average) and high average temperature $(126 \%$ of the average) during both years, and especially in the vegetation period.

In beech, the years with a high decrease in the radial growth were 1979, 1981, 2011, and 2016. On a smaller scale, European beech also reacted to air pollution in the RWI between 1979 and 1986. In the spring of 1979 and 1981, the assimilation apparatus was damaged by late frosts. In 1985, there was a strong outbreak of beech scale (Cryptococcus fagisuga). In 1995, beech crowns were severely damaged by rime, and in 1996, late frosts recurred. Very strong damage to the beech assimilation apparatus occurred at the beginning of the vegetation period in 2011, and milder in 2016. The sharply declining radial growth in 2016-2019 was the same in the case of spruce. For elm, in the period 1972-1974, there was a weaker incidence of Ophiostoma ulmi, and in 1985-1995, there was a strong incidence of Ophiostoma ulmi in synergism with increased air pollution. In 2004-2007 and 2009-2011, Ophiostoma ulmi was recorded there again. In 2014, precipitation was significantly below normal (74\% of the long-term average). In ash, a decrease in the radial growth in 1996 was caused by a very cold year in combination with damage to the assimilation apparatus by a late frost, as in the case of beech. In sycamore, the reduced radial growth in 1993 and 1996 was caused by infestation with Rhytisma acerinum, and in 2011, there was damage to the assimilation apparatus by late frosts. 
Norway spruce

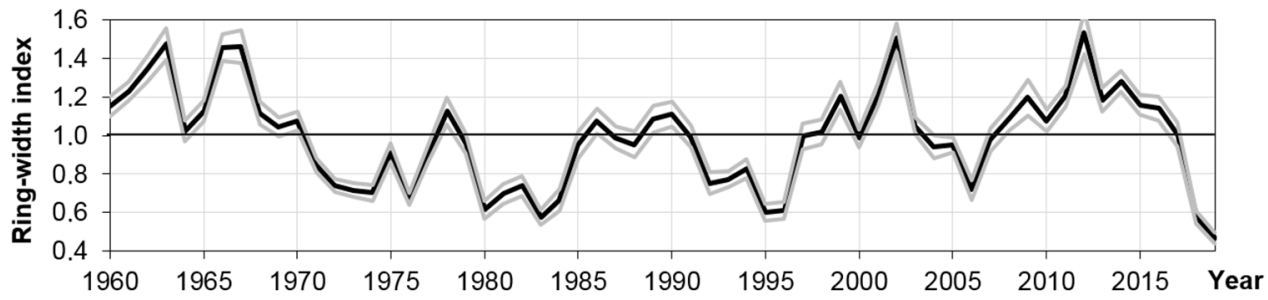

European beech

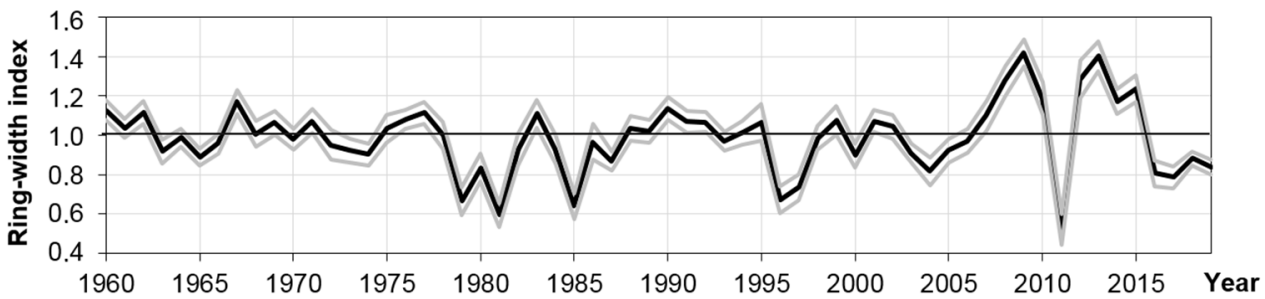

Mountain elm

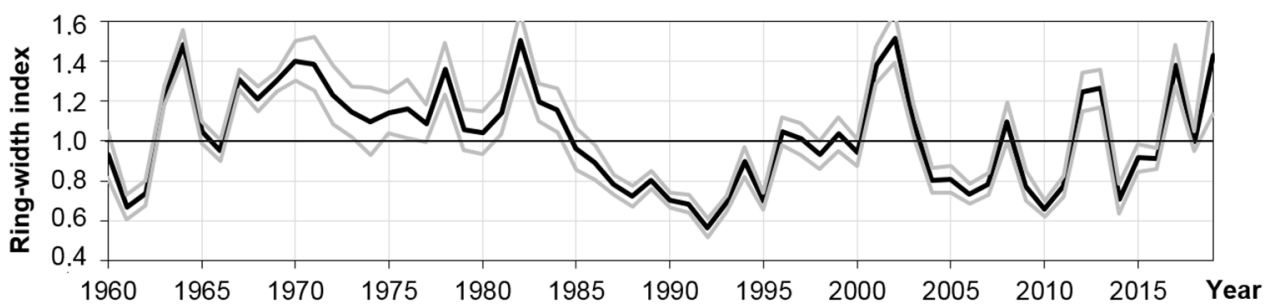

European ash

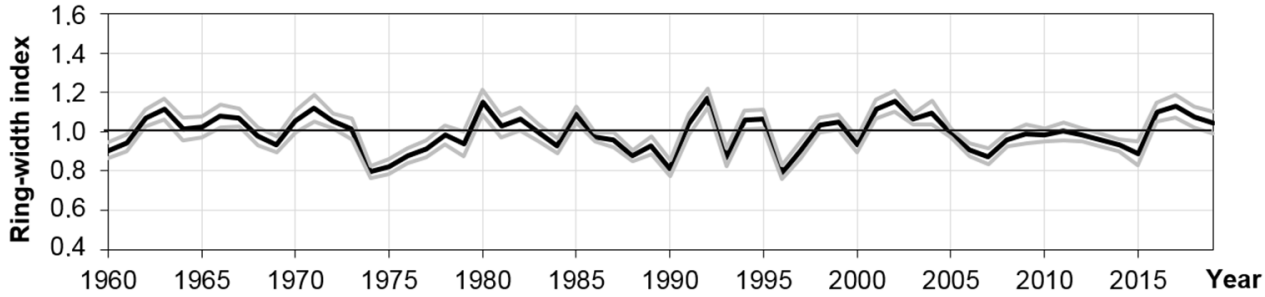

Sycamore maple

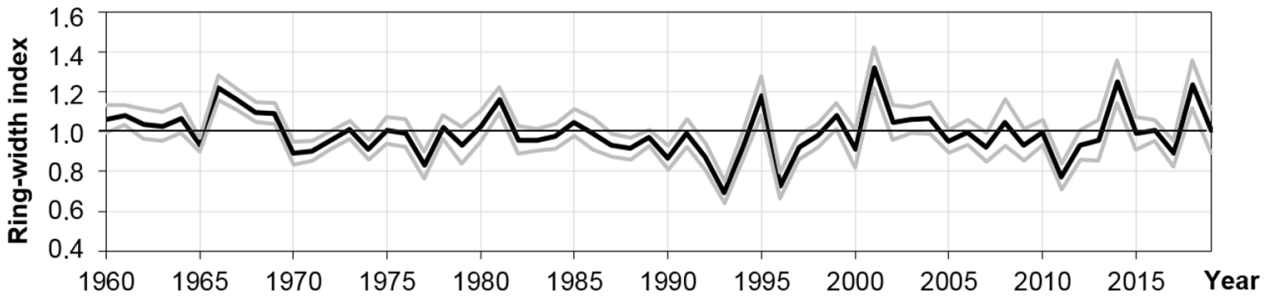

Figure 3. Standardized ring width chronologies of Norway spruce, European beech, mountain elm, European ash, and sycamore maple in the western Krkonoše Mountains in 1960-2019; black line describes ring-width index, and grey line is standard error.

Relative changes in the growth of annual rings and negative pointer years are recorded in Figure 4. The most stable fluctuations in the mean growth deviation are recorded for spruce, where positive and negative growth periods alternate after four to seven years. Spruce recorded two significantly negative years in 2018 and 2019. It is 2018 and 2019 that are abnormally high in terms of temperature averages. The average temperature over the last ten years is $6.5^{\circ} \mathrm{C}$, except in the years 2018 and 2019 , it shows 7.3 and $7.2{ }^{\circ} \mathrm{C}$, which is almost $0.9^{\circ} \mathrm{C}$ above normal. At the same time, in 2018 and 2019, the total precipitation decreased. The average precipitation for the last 10 years was $1190 \mathrm{~mm}$, but the years 2018 and 2019 show only $916 \mathrm{~mm}$ and $1008 \mathrm{~mm}$. In contrast to the growth reactions of spruce, beech showed a more positive average growth deviation, and only one significant 
negative year was recorded in 2011, caused by the aforementioned significant spring frosts, which damaged beech sprouts. Pointer years of spruce and beech are easily visible from the decline in growth in Figure 3. Other tree species (elm, ash, sycamore) do not indicate any significant pointer years in growth.
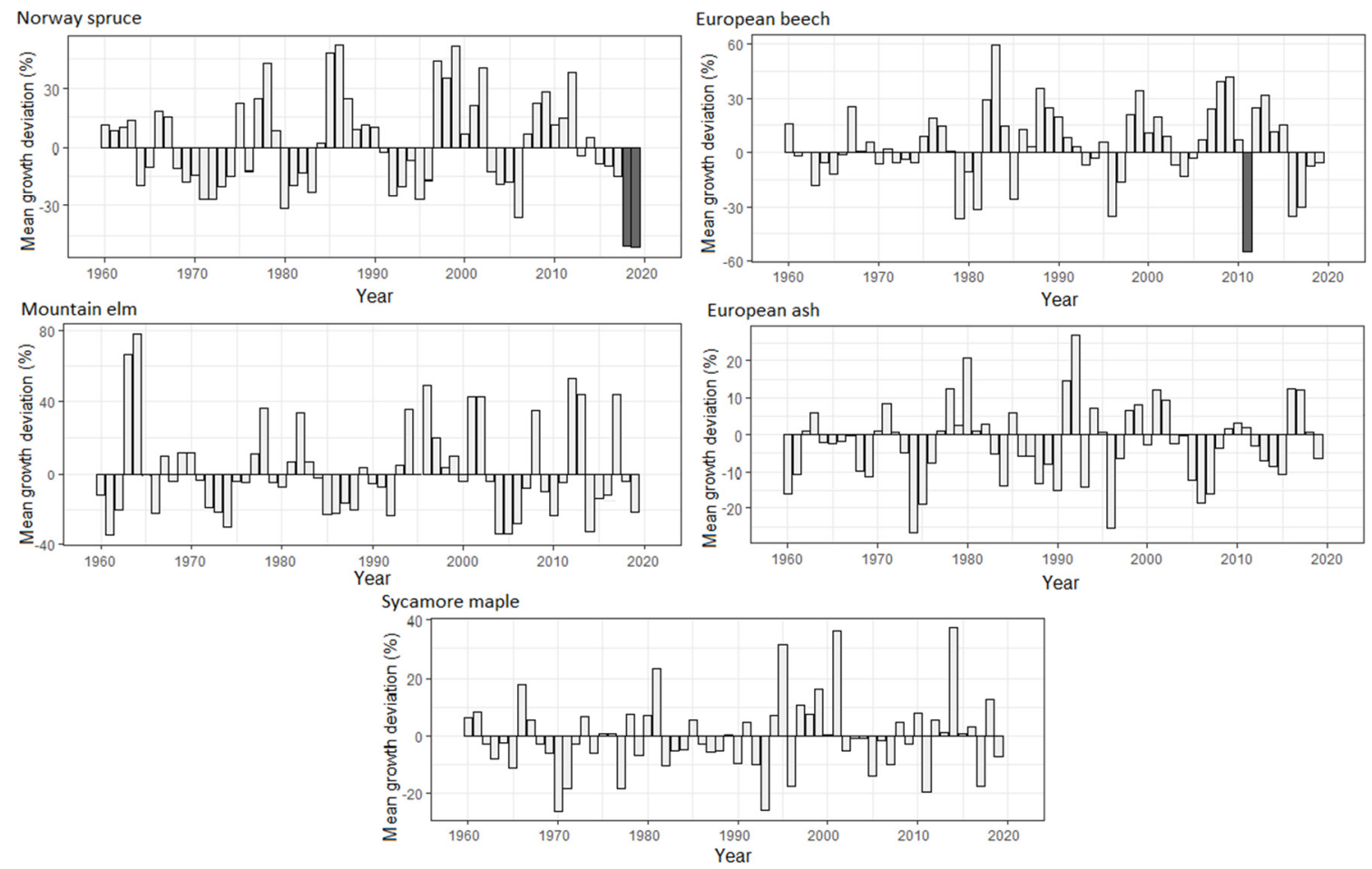

Figure 4. Pointer years (relative growth change) of Norway spruce, European beech, mountain elm, European ash, and sycamore maple in the western Krkonoše Mountains in 1960-2019; dark grey bars-significant pointer years with extremely low radial growth; light grey bars-mean growth deviation.

\subsection{Spectral Analysis in Radial Growth}

Recurring processes in the radial growth of tree species are clearly characterized by a single spectral analysis (Figure 5), which describes the repeated period and the relative magnitude of individual cycles over the periodogram values. Norway spruce, the most represented tree species, goes through the most prominent cycles reaching 1.2 periodogram values. Mountain elm also had large cycles in radial growth (up to 0.6 periodogram values). European beech indicated smaller cycles that reach up to 0.3 periodogram values. The smallest cyclic processes in growth (periodogram values up to 0.1 ) were recorded for European ash and sycamore maple. Spruce recorded 12, 20, and 60-year cycles in the radial growth, beech, 7 and 20-year cycles, elm, 15-year cycles, and sycamore maple, 20-year cycles. Ash did not show any significant cyclic processes in spectral analysis.

Spectral analysis recorded the largest cyclical fluctuations in spruce, while it was also found that with a lower proportion of tree species, cyclical fluctuations in the radial increment decreased. Across tree species, 7, 12, 20, and 60-year cycles in the radial increment were recorded in ring widths. 

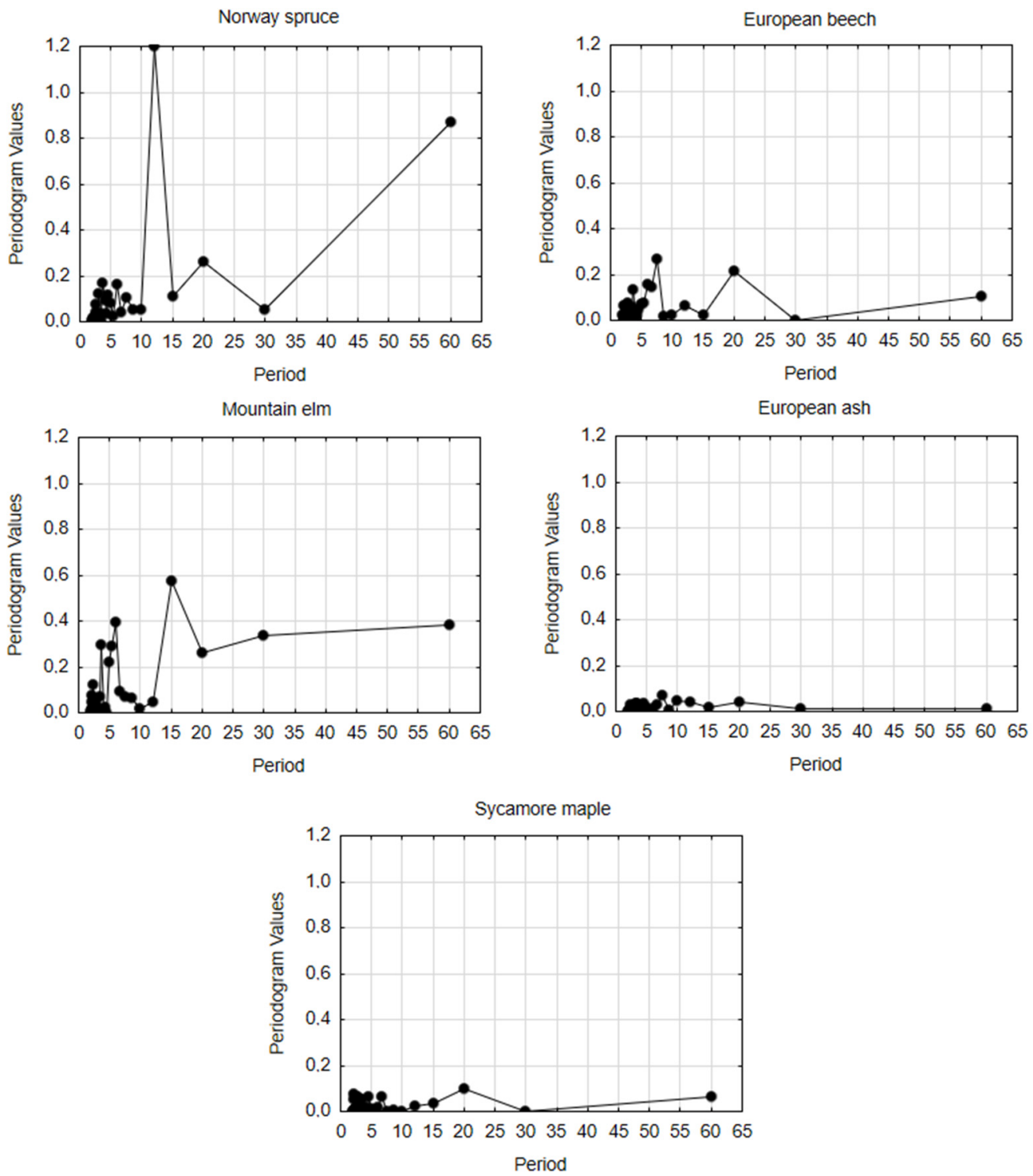

Figure 5. Single spectral analysis of the indexed ring-width chronology of Norway spruce, European beech, mountain elm, European ash, and sycamore maple in the western Krkonoše Mountains in 1960-2019.

\subsection{Effect of Climate on Radial Growth}

The highest effect of climate factor (monthly temperature and precipitation) was observed in European beech (10 significant months) followed by Norway spruce ( 8 months), while the most climate-resistant tree species were European ash (3 months) and sycamore maple (4 months; Figure 6). In beech, the temperature had only a positive effect and precipitation only a negative effect on the radial growth. It was not so obvious for other tree species. In spruce, the monthly climate factors in the previous year had a higher effect on the radial growth compared to the current year, while there was no significant $(p<0.05)$ effect of the previous year in the case of ash. 


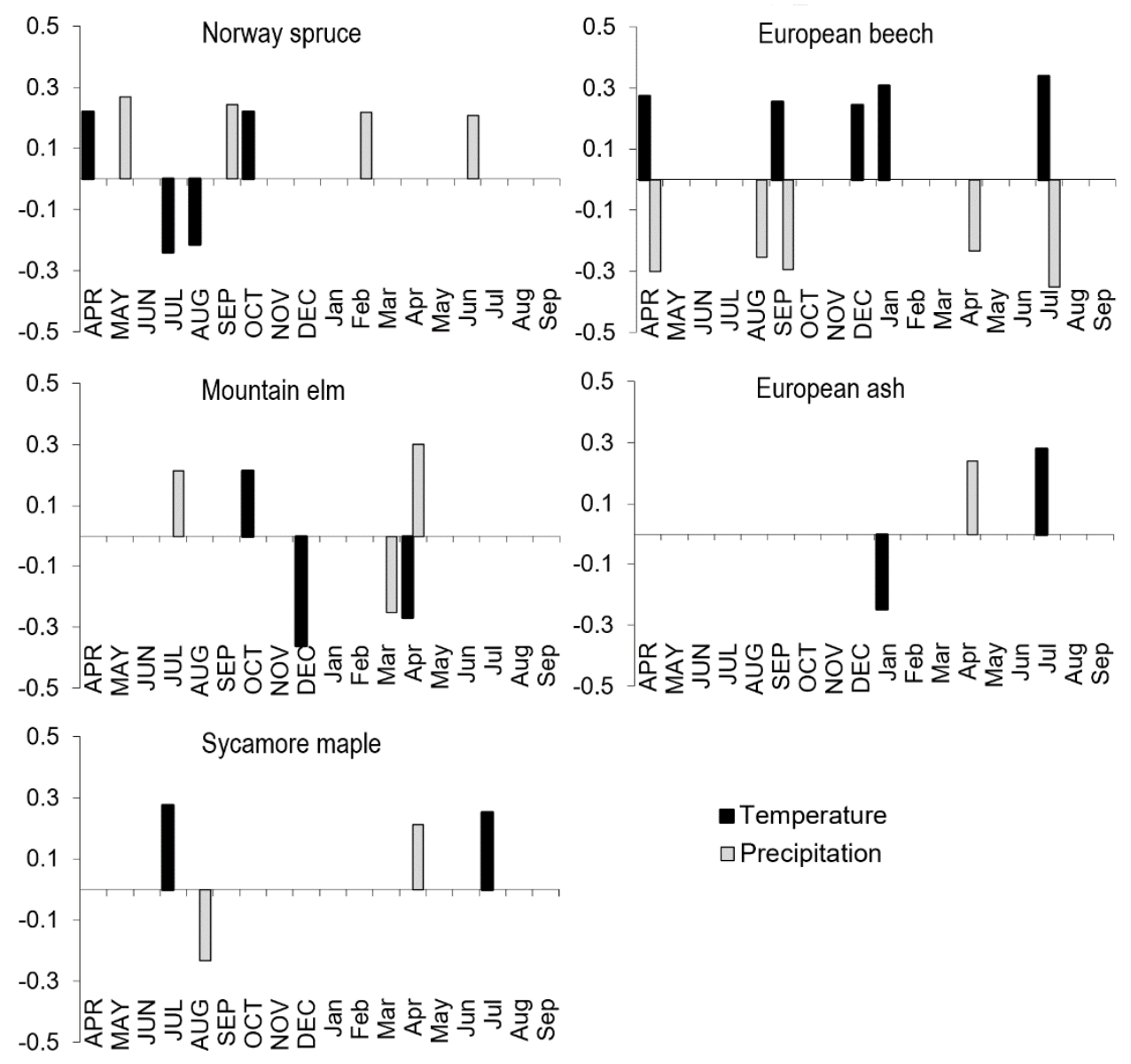

Figure 6. Coefficients of correlation in the regional residual index tree-ring chronology of Norway spruce, European beech, mountain elm, European ash, and sycamore maple with monthly average air temperature and the sum of precipitation from April of the previous year (capital letters) to September of the current year (lower-case letters) in the western Krkonoše Mountains in 1961-2019; only statistically significant $(p<0.05)$ values are shown.

Generally, temperature had a higher effect on the radial growth compared to precipitation in relation to individual months (Figure 6). The most significant months affecting the radial growth were April and July in the current years. July was also the most important month in the previous year. The highest negative correlation $(r=-0.36)$ with the temperature was observed in the radial growth of ash in December of the previous year, or in July of the current year $(r=-0.35)$ in the case of precipitation.

\subsection{Interaction between Climate, Air pollution, and Radial Growth of Tree Species}

The results of PCA are presented in an ordination diagram showing relationships among radial growth, climatic factors (temperature and precipitation), air pollution, and tree species (Figure 7). The $x$-axis illustrates the concentrations of $\mathrm{SO}_{2}$ and radial growth of spruce, and the $y$-axis represents the temperature variability (standard deviation of monthly data). The mean $\mathrm{SO}_{2}$ concentration and mean temperature outside the vegetation period were the highest explanatory variables concerning the radial growth of tree species, while it was the lowest for the sum of precipitation outside the vegetation period and an annual sum of precipitation. In terms of climatic factors, temperature had a higher effect on the radial growth of the studied tree species compared to precipitation. The growth of spruce and elm was the most sensitive tree species to climatic factors, while a low effect was found for maple and ash. 


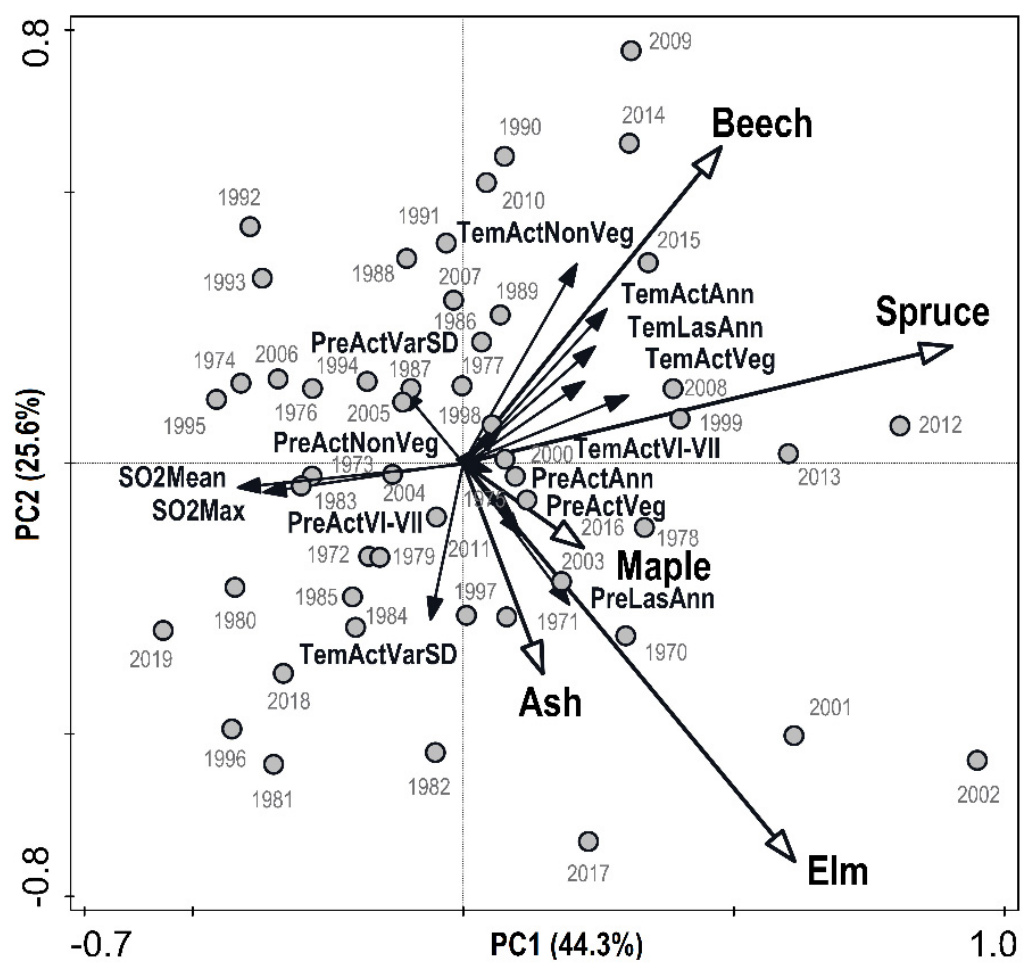

Figure 7. Ordination diagram showing results of the principal component analysis of relationships between radial growth (ring-width index) of five tree species (Norway spruce, European beech, mountain elm, European ash, and sycamore maple), climatic factors (Tem-temperature, Pre-precipitation, Act—of the current year, Las—of the previous year, Ann-annual, Veg-in vegetation period, NonVeg-outside the vegetation period, VI-VII—in June and July, VarSD—monthly variability by standard deviation), and air pollution load (SO2Mean-mean annual concentration of $\mathrm{SO}_{2}, \mathrm{SO} 2 \mathrm{Max}$-maximum concentration of $\mathrm{SO}_{2}$ ) in the western Krkonoše Mountains; symbols • indicate years of period 1970-2019.

According to individual tree species, the growth of beech is strongly affected by temperatures: significant $(p<0.01)$ positive effect of the mean annual temperature in the previous year and the mean temperature outside vegetation period of the current year (Table 6). Similarly, a significant $(p<0.05)$ positive effect of the mean temperature in June and July was observed in ash, while a significant $(p<0.05)$ negative effect of the mean temperature outside the vegetation period was observed only in elm. In terms of climatic variability, high differences in monthly values in temperature had a significant positive effect on growth of $(p<0.01)$ ash and $(p<0.05)$ elm, and negative in $(p<0.05)$ ash in the case of precipitation variability. No significant effect of cumulative climatic factors was observed in maple and spruce; however, spruce was a sensitive tree species to air pollution load. This tree species was significantly $(p<0.05-0.01)$ negatively correlated with mean and $\max \mathrm{SO}_{2}$ concentrations, max $\mathrm{NO}_{\mathrm{X}}$ concentrations, and also with both ozone exposure indicators. However, to a lesser extent, beech showed a significant $(p<0.05)$ negative effect of the mean and max AOT40F and max $\mathrm{NO}_{\mathrm{X}}$ concentrations. Other tree species were not influenced by air pollution load. 
Table 6. Correlation matrix describing interactions between the radial growth of Norway spruce, European beech, mountain elm, European ash, and sycamore maple, as well as precipitation and temperature (1961-2019), and concentrations of $\mathrm{SO}_{2}$ (1970-2012), NOX (1994-2019), and AOT40F (1993-2019) in the western Krkonoše Mountains; significant correlations are designated by ${ }^{*}(p<0.05)$ and ${ }^{* *}(p<0.01)$.

\begin{tabular}{|c|c|c|c|c|c|c|c|c|c|}
\hline RWI & $\begin{array}{c}\text { PreAct } \\
\text { Ann }\end{array}$ & $\begin{array}{c}\text { PreLas } \\
\text { Ann }\end{array}$ & $\begin{array}{c}\text { PreAct } \\
\text { Veg }\end{array}$ & $\begin{array}{l}\text { PreAct } \\
\text { VI-VII }\end{array}$ & $\begin{array}{l}\text { PreAct } \\
\text { NonVeg }\end{array}$ & $\begin{array}{l}\text { PreAct } \\
\text { VarSD }\end{array}$ & $\begin{array}{c}\text { TemAct } \\
\text { Ann }\end{array}$ & $\begin{array}{c}\text { TemLas } \\
\text { Ann }\end{array}$ & $\begin{array}{c}\text { TemAct } \\
\text { Veg }\end{array}$ \\
\hline Beech & -0.07 & -0.12 & -0.07 & $-0.27 *$ & 0.10 & -0.05 & 0.21 & $0.38^{* *}$ & 0.12 \\
\hline Elm & -0.05 & 0.19 & 0.11 & 0.03 & -0.12 & -0.21 & -0.14 & -0.09 & -0.03 \\
\hline Ash & -0.08 & -0.05 & -0.03 & -0.10 & 0.02 & -0.30 * & -0.02 & -0.02 & 0.17 \\
\hline Maple & 0.03 & 0.11 & 0.07 & -0.09 & -0.02 & -0.09 & 0.05 & -0.03 & 0.08 \\
\hline Spruce & 0.04 & 0.14 & 0.12 & 0.14 & -0.10 & -0.15 & 0.02 & 0.05 & 0.01 \\
\hline RWI & $\begin{array}{l}\text { TemAct } \\
\text { VI-VII }\end{array}$ & $\begin{array}{l}\text { TemAct } \\
\text { NonVeg }\end{array}$ & $\begin{array}{l}\text { TemAct } \\
\text { VarSD }\end{array}$ & $\begin{array}{c}\mathrm{SO}_{2} \\
\text { Mean }\end{array}$ & $\begin{array}{l}\mathrm{SO}_{2} \\
\mathrm{Max}\end{array}$ & $\begin{array}{l}\mathrm{NO}_{\mathrm{X}} \\
\text { Mean }\end{array}$ & $\begin{array}{l}\mathrm{NO}_{X} \\
\mathrm{Max}\end{array}$ & $\begin{array}{l}\text { AOT40F } \\
\text { Mean }\end{array}$ & $\begin{array}{c}\text { AOT40F } \\
\text { Max }\end{array}$ \\
\hline Beech & 0.17 & $0.33^{* *}$ & -0.13 & -0.19 & -0.18 & -0.26 & $-0.43 *$ & $-0.39 *$ & $-0.39 *$ \\
\hline Elm & 0.07 & $-0.26^{*}$ & $0.28 *$ & -0.11 & -0.10 & -0.07 & -0.03 & -0.16 & -0.22 \\
\hline Ash & 0.26 * & -0.09 & $0.38^{* *}$ & -0.18 & 0.04 & -0.02 & -0.05 & 0.21 & -0.03 \\
\hline Maple & 0.09 & 0.11 & 0.16 & -0.10 & -0.11 & -0.01 & -0.05 & -0.20 & -0.35 \\
\hline Spruce & -0.08 & 0.03 & -0.03 & $-0.43^{* *}$ & $-0.37^{* *}$ & -0.31 & $-0.43 *$ & $-0.59 * *$ & $-0.59 * *$ \\
\hline
\end{tabular}

Notes: Pre—precipitation, Tem—temperature, Act—of the current year, Las—of the previous year, Ann—annual, Veg—in vegetation period, NonVeg-outside the vegetation period, VI-VII-in June and July, VarSD-monthly variability by standard deviation, $\mathrm{SO}_{2}\left(\mathrm{NO}_{\mathrm{X}}, \mathrm{AOT} 40 \mathrm{~F}\right)$ Mean-mean annual concentration of $\mathrm{SO}_{2}\left(\mathrm{NO}_{\mathrm{X}}, \mathrm{AOT} 40 \mathrm{~F}\right), \mathrm{SO}_{2}\left(\mathrm{NO}_{\mathrm{X}}, \mathrm{AOT} 40 \mathrm{~F}\right) \mathrm{Max}$-maximum concentration of $\mathrm{SO}_{2}\left(\mathrm{NO}_{\mathrm{X}}, \mathrm{AOT} 40 \mathrm{~F}\right)$.

\section{Discussion}

\subsection{Stand Structure and Biodiversity}

In the studied mixed forests, aged 105-151, the stand volume ranged from 597 to $814 \mathrm{~m}^{3} \mathrm{ha}^{-1}$, whereas the mean stand volume was $730 \mathrm{~m}^{3} \mathrm{ha}^{-1}$ in unmanaged stands and $599 \mathrm{~m}^{3} \mathrm{ha}^{-1}$ in managed stands $(-17.9 \%)$. A lower stand volume was observed in mixed scree forests in the eastern (591-699 $\mathrm{m}^{3} \mathrm{ha}^{-1}$; aged 104-158 years) and middle parts (145-195 $\mathrm{m}^{3} \mathrm{ha}^{-1}$; aged 83-107 years) of the Czech Republic [33,90]. Concerning the connection of the stand volume and climate change, many researchers supported an assumption that mixed forest stands provide higher timber production and more resistance to increasing drought periods [61,91], whereas lack of precipitation was also a problem in recent years in our study area. Conversely, comparing the total diversity of unmanaged $(\mathrm{B}=6.555)$ and managed $(\mathrm{B}=6.469)$ forests, we have found no difference $( \pm 1.3 \%)$. Hájek et al. [34] documented a significantly higher total diversity in a comparable site in the Broumovsko Protected Area (B = 7.088-11.277).

In terms of species diversity, the species richness and heterogeneity of the tree layer was low to medium; however, the species evenness ranged from medium to very high in study forest stands. The number of tree species ranged from three to five species per PRPs. Hájek et al. [34] found a significantly higher species diversity in mixed scree forests and counted from 5 to 13 tree species in lower altitudes. In terms of horizontal structure, the distribution of the tree layer was significantly aggregated on two PRPs, whereas on other PRPs, the spatial pattern was random with a prevailing tendency to aggregation. In natural forests, trees are arranged randomly or in aggregates [92,93], while in managed forests, trees are more regularly distributed $[94,95]$. Clustering of trees in natural forests can be caused by an uneven distribution of resources (especially soil depth, skeletality, light availability), interspecific competition, seed dispersal, or management and disturbance histories [96,97]. Even after many years since the end of stand management, the structure of forest stands may retain some consequential characteristics from previous management methods [98,99], as changes in stands caused by management lead to changes in interactions among trees and within the forest structure $[100,101]$. Studies of stand structure in scree and ravine forests have documented both random and aggregated tree arrangements [33,56]. Clustered tree arrangements have been observed, especially in extreme, strongly skeletal, and shallow soils [57], as in our case. A key factor in these forest stands is slope erosion caused by 
unstable debris beds [41]. For these reasons, most scree forests in the Krkonoše National Park have been left to spontaneous development or managed by fine near-nature practices. In our case, in the managed stands, the number of trees was higher by $25.7 \%$ (372 trees ha ${ }^{-1}$ ) compared to stands both left to spontaneous development ( 296 trees ha ${ }^{-1}$ ) and managed stands. For example, Heiri et al. [98] showed that the number of large trees increased within a few decades since the end of management, but the total number of trees had decreased. Burrascano et al. [102] found that the higher density of large live trees and lower total tree density is conclusive in natural forests compared to mature managed forests as in our case. The density of trees in scree forests is generally lower than in the surrounding stands of a given altitudinal vegetation zone [54,103]. The lack of large trees in managed forests is often compensated by the higher overall density of trees in the stand $[104,105]$, but this is not always the case [106,107].

\subsection{Effect of Non-Climatic Factors to Radial Growth}

On a European scale, the increased growth of forest ecosystems has been evident since the 1970s, often attributed to rising temperatures combined with increased nitrogen deposition and increasing $\mathrm{CO}_{2}$ in the atmosphere [22,108]. On the other hand, other researchers have shown a decrease in growth $[109,110]$. From our results, the increase in growth was evident in Norway spruce (46.1\%) and European beech $(20.6 \%)$ in the last 20 years, but was not demonstrated in mountain elm $(0.1 \%)$, sycamore maple $(-12.5 \%)$, and European ash $(-14.9 \%)$, which grow prevailingly in the most extreme conditions of shallow grounded rubble (with the largest skeletality and the shallowest soil profile). In the Czech Republic, however, during this period, the increment of stands was also significantly limited by several negative factors $[39,58]$ including long-term droughts [111,112]. From our results, the influence of negative factors on the radial growth of the studied tree species was clearly visible.

In the Czech Republic, beech is negatively influenced by beech scale, which was reported, e.g., from eastern Krkonoše Mts. by Šimůnek et al. [113] or from Orlické hory Mts. [97]. Spruce is mostly infected by numerous insect pests (especially spruce bark beetle, larch bud moth), hoofed game, and fungal pathogens [114,115]. It was similar in our study, especially in the case of significant negative effects of $\mathrm{SO}_{2}, \mathrm{NO}_{\mathrm{x}}$, and AOT40F concentrations on the growth of spruce, which was the most sensitive tree species of all of the studied samples. In sycamore, we proved the occurrence of only Rhytisma acerinum. The same was true in the scree forests in the Broumov region [33]. In our study, sycamore showed the highest stability in radial growth and resistance to adverse factors. In ash, the situation is similar in the eastern Krkonoše Mts., where fungal pathogens were confirmed [116] as in our study area. Moreover, Ophiostoma ulmi was documented in elm where the most significant damage occurred in the years 1985 to 1997, which is also evidenced by the significantly reduced radial growth. A similar development was reported from various parts of Europe [117,118].

Mina et al. [119] then showed that the growth of individual tree species in mixtures is greater than in monocultures. In general, it can be said that mixed stands are also considered to be more stable because the risk of their disturbance is distributed over a wider range of species-specific properties [120,121]. Similar results regarding the positive effect of mixing on growth were reported by Toïgo et al. [26]. On the other hand, Nothdurft and Engel [122] focused on individual trees in their research and do not share these conclusions. Vannoppen et al. [108] then state that mixed beech and oak stands have a positive effect on beech growth and, conversely, there is a negative effect on oak growth, which justifies the differences in the ecological demands of the tree species. Forrester et al. [123] claim better growth in mixed stands compared to monocultures by more efficient use of underground resources rather than above-ground ones. In mixed stands, better decomposition of the litter as well as the cycle of mineral nutrients may also be a positive factor $[124,125]$. The positive effects of mixing are enhanced by the ability of individual tree species to create different root systems [126], as in our case-the root structures vary from superficial 
through substitute tap to tap roots. The variability of the radial growth of the studied tree species corresponds in general to the type of root system and the character of soil conditions on shallow grounded rubble. This thesis is supported by the results from monospecific stands, where the variability of increment fluctuates considerably depending on different habitat and stand ratios [58]. The positive effect of mixing on the growth depends heavily on climatic and habitat conditions [127].

\subsection{Effect of Climate to Radial Growth}

Climatic factors showed considerable variability during the studied period. In the beginning, the increment was influenced more by cold or frost damage and vice versa at the end of the observed period by higher temperatures and lack of precipitation, which is basically in line with climate dynamics. From the southern regions of Europe, Begović et al. [46] offer a parallel in the positive relationship to summer precipitation and the negative effect of summer temperature. Similar results were obtained by other works [128,129] that deal with climate change. Zimmermann et al. [130], based on their analysis of the sensitivity of growth to climate, showed that both high summer temperatures and low summer precipitation are among the main factors limiting growth. Our results show a large variability affected by winter temperatures, although other studies have shown a positive relationship between winter temperature and the increment $[131,132]$. Carrer et al. [133] showed a decreasing effect of maximum winter temperatures on the radial growth from alpine to subtropical conditions in Italy.

The effects of climate change depend on the tree species [134]. Pretzsch et al. [135] showed that spruce responds to drought by a more pronounced decrease in increment, and significantly negative effects of high temperatures on spruce increment have also been demonstrated [136]. In addition, beech can tolerate sporadic dry summers relatively well, but once they repeat immediately, one after the other, its growth decreases significantly as well [130]. From our results, this is especially evident in recent years (2017-2019), which is in line with the results of Ols et al. [137]. In 1961-2010, the precipitation balance in the individual decades was relatively balanced in our case. Contrary to this, in the years 2010-2019, the average annual total precipitation decreased by $12 \%$, but increased during the vegetation period. At the same time, each decennium warmed by an average of $0.3-0.4{ }^{\circ} \mathrm{C}$ (for $1961-2019$, it was a total of $1.8^{\circ} \mathrm{C}$ ).

In our study, the monthly climate factors in the previous year had a higher effect on the radial growth in spruce and the current year in ash. Based upon long-term research, Vitali et al. [138] confirmed a positive correlation of increment with summer precipitation at lower altitudes. Conversely, their study does not present significant negative correlations with summer temperatures at higher altitudes. At higher altitudes, on the other hand, higher temperatures can have a positive effect on growth due to the earlier onset of cambial activity and xylem cell differentiation $[139,140]$. It is generally accepted that the onset of tree growth after winter rest is markedly sensitive to temperature [141,142]. Moreover, severe frosts can cause a significant reduction in growth [131].

Individual species are affected differently by lack of precipitation, high temperatures, or a combination of both, keeping in mind that they also have different growth reactions [143]. In addition, growth reactions may be specific in site and species [144]. Based on this, it is possible to explain the relatively significant differentiation of our results both by the microhabitat conditions, the species composition, and the different types of root systems. We observed the highest effect of climate factors in beech and spruce, while relatively climate-resistant tree species were ash and sycamore. Tree species may also have different growth responses in terms of their water management strategy, where isohydric species such as spruce close their stomata immediately during drought to maintain a consistent minimum water leaf potential - to prevent high water losses and disruption of water balance in the plant [91]. However, this reaction can lead to reduced photosynthetic activity and an overall reduction in growth $[145,146]$. On the other hand, anisohydric species such as beech close their stomata slowly and thereby may be exposed to hydrologi- 
cal deficiency [147], although photosynthetic activity may continue [148]. In addition, at higher temperatures, there are greater respiratory carbon losses, which lead to reduced carbohydrate availability and may be the cause of reduced growth [149]. In general, trees can handle high temperatures for some time if they have enough water resources to reduce stress conditions [150].

Drought adaptation strategies of trees also differ by tree species [151]. It can lead to better maintenance of osmoregulatory and hydrological functions [152]. Also, mixing deciduous and non-deciduous tree species can lead to better growth, thanks to the diversification of environmental resources, which, eventually, can lead to reduced stress [153]. In our case, for example, spruce can benefit from a greater transmission of light and water through the crowns of other tree species in the spring and winter months, when deciduous trees do not have leaves. Rötzer et al. [154] describe this profitable alliance between spruce and beech. Last but not least, the different type of root system also contributes to increased resource efficiency in stands [155]. Higher spring temperatures are also advantageous for fir and beech due to the reduction in the occurrence of late frosts to which they are sensitive $[22,131]$ and the acceleration of cambial activity $[156,157]$. Mild winter conditions can also contribute to improved growth [158]. Conversely, the correlation of growth and precipitation at the middle and higher altitudes is usually not as significant as the correlation of growth and temperature, especially in the vegetation period [133,159]. Generally, the most significant months (relating to climatic factors) affecting the cambium formation and growth of annual rings are June and July $[160,161]$. Similarly, we concluded that the months of April and July were the most significant in our study.

In the radial growth, 12-year cycles were observed in Norway spruce. These 12-year periods in radial growth may be caused by solar activity that repeats at 8 to 12-year intervals [162]. These cyclical processes have been recorded in the eastern Krkonoše Mountains on European beech stands [7], and have also been confirmed for beech increment in southern Italy [163]. Even Scots pine (Pinus sylvestris L.) in Russia has recorded these 11-year cycles in the annual growth $[164,165]$.

Moreover, four to seven-year cycles were recorded for spruce, beech, and mountain elm. We classify these cycles as the "Schwabe cycle", which is the second harmonic cycle of the sun [166]. These four to seven-year periods are associated with shorter-term temperature and precipitation cycles [163], where, for example, eight-year cycles have been recorded in Germany as most synchronous with vegetation phenology of beech [167].

Longer 20-year cycles were classified as the 22-year Hale cycle, which repeats through meteorological indicators such as temperature and ozone concentration [168] or precipitation [169]. This 22-year cycle has also been found in annual rings in eastern Russia [170] or Slovakia [171]. Longer 60-year cycles in the spectral analysis of spruce and beech are among the influences of the Gleissberg cycle, which is repeated from 70 to 100 years [168], and this cycle is associated with global temperature changes [172].

\section{Conclusions}

The study of radial growth in mixed stands with dominant European beech, Norway spruce, and admixed sycamore maple, European ash, and mountain elm on very stony shallow soils in the Krkonoše Mts. shows that individual tree species respond appropriately to ongoing climate change (increase of temperature and fluctuation in precipitation). While beech and spruce predominantly growing in more favorable habitat conditions (deeper soil profile and less skeletal soils) have increased in the last two decades, the radial growth of sycamore and ash growing in the most extreme soil conditions (very shallow and strongly skeletal soils) decreased. This indicates that a more severe impaction of climate change on forest stands in extreme habitats can be expected. Moreover, the occurrence of negative pointer years with extremely low radial growth and growth variability has increased in the last 20 years. On the other hand, the most vulnerable tree species to growth cyclicity, climate factors, and air pollution load were spruce and beech compared to the resiliency in ash and especially in sycamore. These durable tree species should be supported by silviculture 
practice on these endangered, specific habitats. Their significant stabilizing potential in the most extreme soil conditions of shallow grounded rubble during global climate change is very important. In these habitats and stand conditions, it is essential to fulfill the ecological functions of the forest, especially the soil, climate, and water protection functions, which are becoming more important due to climate change. These mixed scree forests should be systematically maintained by adaptive forest management. These measures should include the supporting of vital deep-rooted deciduous trees (beech, maple, and ash) during sanitary silviculture interventions and the introduction of other native tree species (silver fir, rowan, limes) to increase stand diversity, resilience and sustainability.

Author Contributions: Conceptualization, V.H. and S.V.; Methodology, V.H., S.V. and Z.V.; Software, V.H., V.Š. and A.P.; Validation, V.H., Z.V. and J.C.; Formal analysis, V.H., V.Š. and A.P.; Investigation, V.H., Z.V., I.K. and D.B.; Resources, V.Š.; Data curation, V.H., Z.V. and V.Š.; Writing-original draft preparation, V.H., S.V., Z.V., J.C., M.Š., I.K. and D.B.; Visualization, Z.V. and V.Š.; Supervision, S.V. and Z.V.; Project administration, V.H. and S.V.; Funding acquisition, V.H. All authors have read and agreed to the published version of the manuscript.

Funding: This research was funded by the Czech University of Life Sciences Prague, Faculty of Forestry and Wood Sciences (No. IGA A_20_03).

Data Availability Statement: Monthly climate data and air pollution data for Krkonoše Mountains are available from the Czech Hydrometeorological Institute, Prague (www.chmi.cz). The tree ring data and stand data presented in this study are available on request from the corresponding author.

Acknowledgments: We are grateful to the Czech Hydrometeorological Institute for provided climate data. We would also like to thank Richard Lee Manore, a native speaker, and Jitka Šišáková, an expert in the field, for checking the English. Finally, we thank two anonymous reviewers and editor for their constructive comments and suggestions that helped improve the article.

Conflicts of Interest: The authors declare no conflict of interest.

\section{References}

1. Allen, C.D.; Macalady, A.K.; Chenchouni, H.; Bachelet, D.; McDowell, N.; Vennetier, M.; Kitzberger, T.; Rigling, A.; Breshears, D.D.; Hogg, E.H.; et al. A global overview of drought and heat-induced tree mortality reveals emerging climate change risks for forests. For. Ecol. Manag. 2010, 259, 660-684. [CrossRef]

2. Bošela, M.; Štefančík, I.; Petráš, R.; Vacek, S. The effects of climate warming on the growth of European beechforests depend critically on thinning strategy and site productivity. Agric. For. Meteorol. 2016, 222, 21-31. [CrossRef]

3. Brázdil, R.; Trnka, M.; Dobrovolný, P.; CHromá, K.; Hlavinka, P.; Žalud, Z. Variability of droughts in the Czech Republic, 1881-2006. Theor. Appl. Climatol. 2009, 97, 297-315. [CrossRef]

4. Kolström, M.; Lindner, M.; Vilén, T.; Maroschek, M.; Seidl, R.; Lexer, M.J.; Netherer, S.; Kremer, A.; Delzon, S.; Barbati, A.; et al. Reviewing the science and implementation of climate change adaptation measures in European forestry. Forests 2011, 2, 961-982. [CrossRef]

5. Seidl, R.; Rammer, W.; Lexer, M.J. Climate change vulnerability of sustainable forest management in the Eastern Alps. Clim. Chang. 2011, 106, 225-254. [CrossRef]

6. Martín-Martín, C.; Bunce, R.G.H.; Saura, S.; Elena-Rosselló, R. Changes and interactions between forest landscape connectivity and burnt area in Spain. Ecol. Indic. 2013, 33, 129-138. [CrossRef]

7. Šimůnek, V.; Sharma, R.P.; Vacek, Z.; Vacek, S.; Hůnová, I. Sunspot area as unexplored trend inside radial growth of European beech in Krkonoše Mountains: A forest science from different perspective. Eur. J. For. Res. 2020, 139, 999-1013. [CrossRef]

8. Cukor, J.; Vacek, Z.; Linda, R.; Bílek, L. Carbon sequestration in soil following afforestation of former agricultural land in the Czech Republic. Cent. Eur. For. J. 2017, 63, 97-104. [CrossRef]

9. Hansen, M.C.; Potapov, P.V.; Moore, R.; Hancher, M.; Turubanova, S.A.; Tyukavina, A.; Thau, D.; Stehman, S.V.; Goetz, S.J.; Loveland, T.R.; et al. High-resolution global maps of 21st-century forest cover change. Science 2013, 342, 850-853. [CrossRef]

10. Communication from the Commission to the European Parliament, the Council, the European Economic and Social Committee and the Committee of the Regions. New EU Forest Strategy for 2030; European Commission: Brussels, Belgium, 2021; 27p. Available online: https:/ / ec.europa.eu/info/sites/default/files/communication-new-eu-forest-strategy-2030_with-annex_en.pdf (accessed on 19 August 2021).

11. European Union Forest Action Plan; EUR-Lex-Europa: Brussels, Belgium, 2006. Available online: https://eur-lex.europa.eu/legalcontent/EN/TXT/?uri=LEGISSUM:124277 (accessed on 19 August 2021).

12. Brus, D.J.; Hengeveld, G.M.; Walvoort, D.J.J.; Goedhart, P.W.; Heidema, A.H.; Nabuurs, G.J.; Gunia, K. Statistical mapping of tree species over Europe. Eur. J. For. Res. 2012, 131, 145-157. [CrossRef] 
13. Sabatini, F.M.; Burrascano, S.; Keeton, W.S.; Levers, C.; Lindner, M.; Pötzschner, F.; Verkerk, P.J.; Bauhus, J.; Buchwald, E.; Chaskovsky, O.; et al. Where are Europe's last primary forests? Divers. Distrib. 2018, 24, 1-14. [CrossRef]

14. Ott, E.; Frehner, M.; Frey, H.U.; Lüscher, P. Gebirgsnadelwäulder: Ein Praxisorientierter Leitfaden für Eine Standortsgerechte Waldbehandlung; Verlag Paul Haupt: Bern, Switzerland; Stuttgart, Germany; Wien, Austria, 1997.

15. Zang, C.; Hartl-Meier, C.; Dittmar, C.; Rothe, A.; Menzel, A. Patterns of drought tolerance in major European temperate forest trees: Climatic drivers and levels of variability. Glob. Chang. Biol. 2014, 20, 3767-3779. [CrossRef] [PubMed]

16. Klopčič, M.; Mina, M.; Bugmann, H.; Bončina, A. The prospects of silver fir (Abies alba Mill.) and Norway spruce (Picea abies (L.) Karst) in mixed mountain forests under various management strategies, climate change and high browsing pressure. Eur. J. For. Res. 2017, 136, 1071-1090. [CrossRef]

17. Diaci, J.; Rozman, J.; Rozman, A. Regeneration gap and microsite niche artitioning in a high alpine forest: Are Norway spruce seedlings more drought-tolerant than beech seedlings? For. Ecol. Manag. 2020, 455, 117688. [CrossRef]

18. Slanař, J.; Vacek, Z.; Vacek, S.; Bulušek, D.; Cukor, J.; Štefančík, I.; Bílek, L.; Krl, J. Long-term transformation of submontane spruce-beech forests in the Jizerské hory Mts.: Dynamics of natural regeneration. Cent. Eur. For. J. 2017, 63, 212-224. [CrossRef]

19. Štefančík, I.; Štefančík, L. Effect of long-term tending on qualitative and quantitative production in mixed stands of spruce, fir and beech on Motyčky research plot. J. For. Sci. 2003, 49, 108-124. [CrossRef]

20. Knoke, T.; Ammer, C.; Stimm, B.; Mosandl, R. Admixing broadleaved to coniferous tree species: A review on yield, ecological stability and economics. Eur. J. For. Res. 2008, 127, 89-101. [CrossRef]

21. Ruosch, M.; Spahni, R.; Joos, F.; Henne, P.D.; van der Knaap, W.O.; Tinner, W. Past and future evolution of Abies alba forests in Europe-Comparison of a dynamic vegetation model with palaeo data and observations. Glob. Chang. Biol. 2016, 22, 727-740. [CrossRef]

22. Mikulenka, P.; Prokůpková, A.; Vacek, Z.; Vacek, S.; Bulušek, D.; Simon, J.; Šimůnek, V.; Hájek, V. Effect of climate and air pollution on radial growth of mixed forests: Abies alba Mill. vs. Picea abies (L.) Karst. Cent. Eur. For. J. 2020, 66, 23-36. [CrossRef]

23. Chamagne, J.; Tanadini, M.; Frank, D.; Matula, R.; Paine, C.E.T.; Philipson, C.D.; Svátek, M.; Turnbull, L.A.; Volařík, D.; Hector, A. Forest diversity promotes individual tree growth in central European forest stands. J. Appl. Ecol. 2017, 54, 71-79. [CrossRef]

24. Jactel, H.; Gritti, E.S.; Drössler, L.; Forrester, D.I.; Mason, W.L.; Morin, X.; Pretzsch, H.; Castagneyrol, B. Positive biodiversityProductivity relationships in forests: Climate matters. Biol. Lett. 2018, 14, 20170747. [CrossRef]

25. Bošela, M.; Tobin, B.; Šebeň, V.; Petráš, R.; Larocque, G.R.; Šeben, V.; Petráš, R.; Larocque, G.R. Different mixtures of Norway spruce, silver fir, and European beech modify competitive interactions in central Europeanmaturemixed forests. Can. J. For. Res. 2015, 45, 1577-1586. [CrossRef]

26. Toïgo, M.; Vallet, P.; Perot, T.; Bontemps, J.D.; Piedallu, C.; Courbaud, B. Overyielding in mixed forests decreases with site productivity. J. Ecol. 2015, 103, 502-512. [CrossRef]

27. Metz, J.; Annighöfer, P.; Schall, P.; Zimmermann, J.; Kahl, T.; Schulze, E.D.; Ammer, C. Site-adapted admixed tree species reduce drought susceptibility of mature European beech. Glob. Chang. Biol. 2016, 22, 903-920. [CrossRef]

28. Vitali, V.; Büntgen, U.; Bauhus, J. Silver fir and Douglas fir are more tolerant to extreme droughts than Norway spruce in south-western Germany. Glob. Chang. Biol. 2017, 23, 5108-5119. [CrossRef] [PubMed]

29. Lindner, M.; Maroschek, M.; Netherer, S.; Kremer, A.; Barbati, A.; Garcia-Gonzalo, J.; Seidl, R.; Delzon, S.; Corona, P.; Kolström, M.; et al. Climate change impacts, adaptive capacity, and vulnerability of European forest ecosystems. For. Ecol. Manag. 2010, 259, 698-709. [CrossRef]

30. Fyllas, N.M.; Christopoulou, A.; Galanidis, A.; Michelaki, C.Z.; Dimitrakopoulos, P.G.; Fulé, P.Z.; Arianoutsou, M. Tree growthclimate relationships in a forest-plot network on Mediterranean mountains. Sci. Total Environ. 2017, 598, 393-403. [CrossRef] [PubMed]

31. Kolář, T.; Čermák, P.; Trnka, M.; Žid, T.; Rybníček, M. Temporal changes in the climate sensitivity of Norway spruce and European beech along an elevation gradient in Central Europe. Agric. For. Meteorol. 2017, 239, 24-33. [CrossRef]

32. Taylor, A.R.; Boulanger, Y.; Price, D.T.; Cyr, D.; McGarrigle, E.; Rammer, W.; Kershaw, J.A. Rapid 21st century climate change projected to shift composition and growth of Canada's Acadian Forest Region. For. Ecol. Manag. 2017, 405, 284-294. [CrossRef]

33. Vacek, S.; Prokupková, A.; Vacek, Z.; Bulu ek, D.; Simunek, V.; Králícek, I.; Prausová, R.; Hájek, V. Growth response of mixed beech forests to climate change, various management and game pressure in Central Europe. J. For. Sci. 2019, 65, 116-129. [CrossRef]

34. Hájek, V.; Vacek, Z.; Vacek, S.; Bílek, L.; Prausová, R.; Linda, R.; Bulušek, D.; Králíček, I. Changes in diversity of protected scree and herb-rich beech forest ecosystems in Central Europe over 55 years. Cent. Eur. For. J. 2020, 66, 202-2017. [CrossRef]

35. Schütz, J.P.; Götz, M.; Schmid, W.; Mandallaz, D. Vulnerability of spruce (Picea abies) and beech (Fagus sylvatica) forest stands to storms and consequences for silviculture. Eur. J. For. Res. 2006, 125, 291-302. [CrossRef]

36. Bulušek, D.; Vacek, Z.; Vacek, S.; Král, J.; Bílek, L.; Králíček, I. Spatial pattern of relict beech (Fagus sylvatica L.) forests in the Sudetes of the Czech Republic and Poland. J. For. Sci. 2016, 62, 293-305. [CrossRef]

37. Solberg, S.; Dobbertin, M.; Reinds, G.J.; Lange, H.; Andreassen, K.; Fernandez, P.G.; Hildingsson, A.; de Vries, W. Analyses of the impact of changes in atmospheric deposition and climate on forest growth in European monitoring plots: A stand growth approach. For. Ecol. Manag. 2009, 258, 1735-1750. [CrossRef] 
38. Vacek, S.; Hůnová, I.; Vacek, Z.; Hejcmanová, P.; Podrázský, V.; Král, J.; Putalová, T.; Moser, W.K. Effects of air pollution and climatic factors on Norway spruce forests in the Orlické hory Mts. (Czech Republic), 1979-2014. Eur. J. For. Res. 2015, 134, 1127-1142. [CrossRef]

39. Vacek, Z.; Vacek, S.; Slanař, J.; Bílek, L.; Bulušek, D.; Štefančík, I.; Králíček, I.; Vančura, K. Adaption of Norway spruce and European beech forests under climate change: From resistance to close-to-nature silviculture. Cent. Eur. For. J. 2019, 65, 129-144. [CrossRef]

40. Zapletal, M.; Juran, S.; Krpes, V.; Michna, K.; Cudlin, P.; Edwards, M. Effect of ozone flux on selected structural and antioxidant characteristics of a mountain norway spruce forest. Balt. For. 2018, 24, 261-267.

41. Vacek, S.; Podrázský, V.; Mikeska, M.; Moser, W.K. Introskeletal erosion threat in mountain forests of the Czech Republic. J. For. Sci. 2003, 49, 313-320. [CrossRef]

42. Machar, I.; Vlckova, V.; Bucek, A.; Vozenilek, V.; Salek, L.; Jerabkova, L. Modelling of climate conditions in forest vegetation zones as a support tool for forest management strategy in European beech dominated forests. Forests 2017, 8, 82. [CrossRef]

43. Castagneri, D.; Battipaglia, G.; Von Arx, G.; Pacheco, A.; Carrer, M. Tree-ring anatomy and carbon isotope ratio show both direct and legacy effects of climate on bimodal xylem formation in Pinus pinea. Tree Physiol. 2018, 38, 1098-1109. [CrossRef] [PubMed]

44. Keenan, T.F.; Gray, J.; Friedl, M.A.; Toomey, M.; Bohrer, G.; Hollinger, D.Y.; Munger, J.W.; O'Keefe, J.; Schmid, H.P.; Wing, I.S.; et al. Net carbon uptake has increased through warming-induced changes in temperate forest phenology. Nat. Clim. Chang. 2014, 4, 598. [CrossRef]

45. Babushkina, E.; Zhirnova, D.; Belokopytova, L.; Vaganov, E. Warming induced changes in wood matter accumulation in tracheid walls of spruce. J. Mt. Sci. 2020, 17, 16-30. [CrossRef]

46. Begović, K.; Rydval, M.; Mikac, S.; Čupić, S.; Svobodova, K.; Mikoláš, M.; Kozák, D.; Kameniar, O.; Frankovič, M.; Pavlin, J.; et al. Climate-growth relationships of Norway Spruce and silver fir in primary forests of the Croatian Dinaric mountains. Agric. For. Meteorol. 2020, 288-289, 108000. [CrossRef]

47. Yousefpour, R.; Temperli, C.; Jacobsen, J.B.; Thorsen, B.J.; Meilby, H.; Lexer, M.J.; Lindner, M.; Bugmann, H.; Borges, J.G.; Palma, J.H.N.; et al. A framework for modeling adaptive forest management and decision making under climate change. Ecol. Soc. 2017, 22, 40. [CrossRef]

48. Vacek, Z.; Prokůpková, A.; Vacek, S.; Cukor, J.; Bílek, L.; Gallo, J.; Bulušek, D. Silviculture as a tool to support stability and diversity of forests under climate change: Study from Krkonoše Mountains. Cent. Eur. For. J. 2020, 66, 116-129. [CrossRef]

49. Podrázský, V.; Vacek, S.; Vacek, Z.; Raj, A.; Mikeska, M.; Boček, M.; Schwarz, O.; Hošek, J.; Šach, F.; Černohous, V.; et al. Půdy Lesư a Ekosystému nad Horní Hranicí Lesa v Národních Parcích Krkonoš; Kostelec nad Černými lesy, Lesnická práce, s. r. o.: Kostelec nad Černými lesy, Czech Republic, 2010.

50. Neuhäuslová, Z.; Blažková, D.; Grulich, V.; Husová, M.; Chytrý, M.; Jeník, J.; Jirásek, J.; Kolbek, J.; Kropáč, Z.; Ložek, V.; et al. Mapa Potenciální Přirozené Vegetace České Republiky; Academia: Praha, Czech Republic, 1998.

51. Chytrý, M.; Kučera, T.; Kočí, M.; Grulich, V.; Lustyk, P. (Eds.) Katalog Biotopů České Republiky; Agentura Ochrany Přírody a Krajiny ČR: Praha, Czech Republic, 2010.

52. Vacek, S.; Vacek, Z.; Kalousková, I.; Cukor, J.; Bílek, L.; Moser, W.K.; Bulušek, D.; Podrázský, V.; Řeháček, D. Sycamore maple (Acer pseudoplatanus L.) stands on former agricultural land in the sudetes-Evaluation of ecological value and production potential. Dendrobiology 2018, 79, 61-76. [CrossRef]

53. Vacek, S.; Moucha, P.; Bılek, L.; Mikeska, M. Péče o Lesní Ekosystémy v Chráněných Územích ČR; Ministerstvo Životního Prostředí: Praha, Czech Republic, 2012.

54. Bodziarczyk, J.; Szwagrzyk, J. Species composition and structure of forest stands in Phyllitido-Aceretum community. Ekol. Pol. 1995, 43, 153-173.

55. Paillet, Y.; Archaux, F.; Breton, V.; Brun, J.J. A quantitative assessment of the ecological value of sycamore maple habitats in the French Alps. Ann. For. Sci. 2008, 65, 713. [CrossRef]

56. Baran, J.; Bodziarczyk, J. Forest stands in Phyllitido-Aceretum community occuring on limestone rocks and shelves-comparison of their structure in strictly protected and managed forests. Pol. J. Ecol. 2019, 67, 105-121. [CrossRef]

57. Baran, J.; Pielech, R.; Kauzal, P.; Kukla, W.; Bodziarczyk, J. Influence of forest management on stand structure in ravine forests. For. Ecol. Manag. 2020, 463, 118018. [CrossRef]

58. Putalová, T.; Vacek, Z.; Vacek, S.; Štefančík, I.; Bulušek, D.; Král, J. Tree-ring widths as an indicator of air pollution stress and climate conditions in different Norway spruce forest stands in the Krkonoše Mts. Cent. Eur. For. J. 2019, 65, 21-33. [CrossRef]

59. Köppen, W. Grundriss der Klimakunde. Zweite, Verbesserte Auflage der Klimate der Erde; Walter de Gruyter \& Co.: Berlin, Germany, 1931.

60. Král, J.; Vacek, S.; Vacek, Z.; Putalová, T.; Bulušek, D.; Štefančík, I. Structure, development and health status of spruce forests affected by air pollution in the western Krkonoše Mts. in 1979-2014. Cent. Eur. For. J. 2015, 61, 175-187. [CrossRef]

61. Vacek, Z.; Prokůpková, A.; Vacek, S.; Bulušek, D.; Šimůnek, V.; Hájek, V.; Králíček, I. Mixed vs. monospecific mountain forests in response to climate change: Structural and growth perspectives of Norway spruce and European beech. For. Ecol. Manag. 2021, 488, 119019. [CrossRef]

62. Fabrika, M.; Ďurský, J. Stromové Ri̊stové Simulátory; EFRA: Zvolen, Slovakia, 2005.

63. Petráš, R.; Pajtík, J. Sústava česko-slovenských objemových tabuliek drevín. Lesn. Časopis 1991, 37, 49-56.

64. Reineke, L.H. Perfecting a stand-density index for even-aged forests. J. Agric. Res. 1933, 46, 627-638. 
65. Crookston, N.L.; Stage, A.R. Percentcanopy Cover and Stand Structural Statistics Fromthe Forest Vegetation Simulator; RMRS GTR-24; USDA Forest Service, Rocky Mountain Research Station: Ogden, UT, USA, 1999.

66. Halaj, J.; Řehák, J. Rastové Tabul'ky Hlavných Drevín ČSSR [Yield Tables of the Main Tree Species of Czechoslovakia]; Príroda: Bratislava, Slovakia, 1987.

67. Sharma, R.P.; Vacek, Z.; Vacek, S. Modeling individual tree height to diameter ratio for Norway spruce and European beech in Czech Republic. Trees 2016, 30, 1969-1982. [CrossRef]

68. Sharma, R.P.; Vacek, Z.; Vacek, S.; Kučera, M. A nonlinear mixed-effects height-to-diameter ratio model for several tree species based on Czech national forest inventory data. Forests 2019, 10, 70. [CrossRef]

69. Slodicak, M.; Novak, J. Silvicultural measures to increase the mechanical stability of pure secondary Norway spruce stands before conversion. For. Ecol. Manag. 2006, 224, 252-257. [CrossRef]

70. Margalef, R. Information theory in ecology. Gen. Syst. 1958, 3, 36-71.

71. Shannon, C.E. A Mathematical Theory of Communication. Bell Syst. Tech. J. 1948, 27, 379-423. [CrossRef]

72. Pielou, E.C. Ecological Diversity; Wiley: New York, NY, USA, 1975.

73. Clark, P.J.; Evans, F.C. Distance to Nearest Neighbor as a Measure of Spatial Relationships in Populations. Ecology 1954, 35, 445-453. [CrossRef]

74. Pretzsch, H. Wissen nutzbar machen für das Management von Waldökosystemen. Allg. Forstz. Der Wald 2006, 61, 1158-1159.

75. Jaehne, S.; Dohrenbusch, A. Ein Verfahren zur Beurteilung der Bestandesdiversität. Eur. J. For. Res. 1997, 116, 333-345. [CrossRef]

76. Füldner, K. Strukturbeschreibung in Mischbeständen. Forstarchiv 1995, 66, 235-606.

77. Bílek, L.; Remeš, J.; Zahradnik, D. Managed versus unmanaged. Structure of beech forest stands "Fagus sylvatica L." after 50 years of development, Central Bohemian. For. Syst. 2011, 20, 122-138. [CrossRef]

78. Larsson, L.-A. Cybis Elektronik \& Data AB, Saltsjöbaden, Sweden, 2010. Available online: http:/ / www.cybis.se/ (accessed on 19 August 2021).

79. Team R Core. A Language and Environment for Statistical Computing; R Foundation for Statistical Computing: Vienna, Austria, 2018.

80. Bunn, A.; Korpela, M. Chronology Building in dplR; R Foundation for Statistical Computing: Vienna, Austria, 2018 ; pp. 1-13.

81. Bunn, A.G. Statistical and visual crossdating in R using the dplR library. Dendrochronologia 2010, 28, 251-258. [CrossRef]

82. Bunn, A.G. A dendrochronology program library in R (dplR). Dendrochronologia 2008, 26, 115-124. [CrossRef]

83. Cook, E.R.; Shiyatov, S.G.; Mazepa, V.S.; Ecology, A.; Branch, U. Methods of Dendrochronology Applications; Tree-Ring Laboratory, Lamont-Ooherty Geological Observatory, Columbia University: New York, NY, USA, 1990.

84. Fritts, H.C. Tree Rings and Climate; Academic Press: Tucson, AZ, USA, 1976.

85. Speer, J.H. Fundamentals of Tree-Ring Research. In Geoarchaeology; University of Arizona Press: Tuscon, AZ, USA, 2010.

86. Schweingruber, F.H.; Eckstein, D.; Serre-Bachet, F.; Braker, O.U. Identification, Presentation and Interpretation of Event Years and Pointer Years in Dendrochronology. Dendrochronologia 1990, 8, 9-38.

87. Neuwirth, B.; Schweingruber, F.H.; Winiger, M. Spatial patterns of central European pointer years from 1901 to 1971. Dendrochronologia 2007, 24, 79-89. [CrossRef]

88. Biondi, F.; Waikul, K. Dendroclim 2002: AC++ program for statistical calibration of climate signals in tree ring chronologie. Comput. Geosci. 2004, 30, 303-311. [CrossRef]

89. Šmilauer, P.; Lepš, J. Multivariate Analysis of Ecological Data Using Canoco 5; Cambridge University Press: Cambridge, UK, 2014.

90. Vacek, Z.; Vacek, S.; Bílek, L.; Král, J.; Ulbrichová, I.; Simon, J.; Bulušek, D. Impact of applied silvicultural systems on spatial pattern of hornbeam-oak forests. Cent. Eur. For. J. 2018, 64, 33-45. [CrossRef]

91. del Río, M.; Schütze, G.; Pretzsch, H. Temporal variation of competition and facilitation in mixed species forests in Central Europe. Plant Biol. 2014, 16, 166-176. [CrossRef]

92. Vacek, S.; Vacek, Z.; Podrázský, V.; Bílek, L.; Bulušek, D.; Štefančík, I.; Remeš, J.; Štícha, V.; Ambrož, R. Structural diversity of autochthonous beech forests in Broumovské stěny National Nature Reserve, Czech Republic. Austrian J. For. Sci. 2014, 131, 191-214.

93. Ghalandarayeshi, S.; Nord-Larsen, T.; Johannsen, V.K.; Larsen, J.B. Spatial patterns of tree species in Suserup Skov-A seminatural forest in Denmark. For. Ecol. Manag. 2017, 406, 391-401. [CrossRef]

94. Bílek, L.; Remeš, J.; Podrázský, V.; Rozenbergar, D.; Diaci, J.; Zahradnik, D. Gap regeneration in near-natural European beech forest stands in Central Bohemia-The role of heterogeneity and micro-habitat factors. Dendrobiology 2014, 71, 59-71. [CrossRef]

95. Vacek, S.; Vacek, Z.; Bílek, L.; Simon, J.; Remeš, J.; Hůnová, I.; Král, J.; Putalová, T.; Mikeska, M. Structure, regeneration and growth of scots pine (Pinus sylvestris L.) stands with respect to changing climate and environmental pollution. Silva Fenn. 2016, 50, 1564. [CrossRef]

96. Kang, H.; Zheng, Y.; Liu, S.; Chai, Z.; Chang, M.; Hu, Y.; Li, G.; Wang, D. Population structure and spatial pattern of predominant tree species in a pine-oak mosaic mixed forest in the qinling mountains, China. J. Plant Interact. 2017, 12, 78-86. [CrossRef]

97. Králíček, I.; Vacek, Z.; Vacek, S.; Remeš, J.; Bulušek, D.; Král, J.; Štefančík, I.; Putalová, T. Dynamics and structure of mountain autochthonous spruce-beech forests: Impact of hilltop phenomenon, air pollutants and climate. Dendrobiology 2017, 77, 121-139. [CrossRef]

98. Heiri, C.; Wolf, A.; Rohrer, L.; Bugmann, H. Forty years of natural dynamics in Swiss beech forests: Structure, composition, and the influence of former management. Ecol. Appl. 2009, 19, 1920-1934. [CrossRef] 
99. Horvat, V.; De Vicuña, J.G.; Biurrun, I.; García-Mijangos, I. Managed and unmanaged silver fir-beech forests show similar structural features in the western pyrenees. iForest 2018, 11, 698-704. [CrossRef]

100. Altman, J.; Hédl, R.; Szabó, P.; Mazůrek, P.; Riedl, V.; Müllerová, J.; Kopecký, M.; Doležal, J. Tree-Rings Mirror Management Legacy: Dramatic Response of Standard Oaks to Past Coppicing in Central Europe. PLoS ONE 2013, 8, e55770. [CrossRef]

101. Trouvé, R.; Bontemps, J.D.; Seynave, I.; Collet, C.; Lebourgeois, F. Stand density, tree social status and water stress influence allocation in height and diameter growth of Quercus petraea (Liebl.). Tree Physiol. 2015, 35, 1035-1046. [CrossRef] [PubMed]

102. Burrascano, S.; Keeton, W.S.; Sabatini, F.M.; Blasi, C. Commonality and variability in the structural attributes of moist temperate old-growth forests: A global review. For. Ecol. Manag. 2013, 291, 458-479. [CrossRef]

103. Vacek, S.; Vacek, Z.; Bílek, L.; Nosková, I.; Schwarz, O. Structure and development of forest stands on permanent research plots in the Krkonoše Mts. J. For. Sci. 2010, 56, 518-530. [CrossRef]

104. Wesely, N.; Fraver, S.; Kenefic, L.; Weiskittel, A.; Ruel, J.-C.; Thompson, M.; White, A. Structural attributes of old-growth and partially harvested northern whitecedar stands in Northeastern North America. Forests 2018, 9, 376. [CrossRef]

105. Burton, J.I.; Zenner, E.K.; Frelich, L.E.; Cornett, M.W. Patterns of plant community structure within and among primary and second-growth northern hardwood forest stands. For. Ecol. Manag. 2009, 258, 2556-2568. [CrossRef]

106. Commarmot, B.; Bachofen, H.; Bundziak, Y.; Bürgi, A.; Ramp, B.; Shparyk, Y.; Sukhariuk, D.; Viter, R.; Zingg, A. Structures of virgin and managed beech forests in Uholka (Ukraine) and Sihlwald (Switzerland): A comparative study. Proc. For. Snow Landsc. Res. 2005, 79, 45-56.

107. Dieler, J.; Uhl, E.; Biber, P.; Müller, J.; Rötzer, T.; Pretzsch, H. Effect of forest stand management on species composition, structural diversity, and productivity in the temperate zone of Europe. Eur. J. For. Res. 2017, 136, 739-766. [CrossRef]

108. Vannoppen, A.; Kint, V.; Ponette, Q.; Verheyen, K.; Muys, B. Tree species diversity impacts average radial growth of beech and oak trees in belgium, not their long-term growth trend. For. Ecosyst. 2019, 6, 10. [CrossRef]

109. Tognetti, R.; Lasserre, B.; Di Febbraro, M.; Marchetti, M. Modeling regional drought-stress indices for beech forests in Mediterranean mountains based on tree-ring data. Agric. For. Meteorol. 2019, 265, 110-120. [CrossRef]

110. Bošela, M.; Lukac, M.; Castagneri, D.; Sedmák, R.; Biber, P.; Carrer, M.; Konôpka, B.; Nola, P.; Nagel, T.A.; Popa, I.; et al. Contrasting effects of environmental change on the radial growth of co-occurring beech and fir trees across Europe. Sci. Total Environ. 2018, 615, 1460-1469. [CrossRef]

111. Bošela, M.; Tumajer, J.; Cienciala, E.; Dobor, L.; Kulla, L.; Marčiš, P.; Popa, I.; Sedmák, R.; Sedmáková, D.; Sitko, R.V.; et al. Climate warming induced synchronous growth decline in Norway spruce populations across biogeographical gradients since 2000. Sci. Total Environ. 2020, 752, 141794. [CrossRef]

112. UNECE. FAO State of Europe's forests 2011. In Status \& Trends in Sustainable Forest Management in Europe; UNECE, FAO: Rome, Italy, 2011.

113. Šimůnek, V.; Vacek, Z.; Vacek, S.; Králíček, I.; Vančura, K. Growth variability of European beech (Fagus sylvatica L.) natural forests: Dendroclimatic study from Krkonoše National Park. Cent. Eur. For. J. 2019, 65, 3-11. [CrossRef]

114. Krejcí, F.; Vacek, S.; Bílek, L.; Mikeska, M.; Hejcmanová, P.; Vacek, Z. The effects of climatic conditions and forest site types on disintegration rates in Picea abies occurring at the Modrava Peat Bogs in the Šumava National Park. Dendrobiology 2013, 70, 35-44. [CrossRef]

115. Vacek, Z.; Vacek, S.; Bílek, L.; Remeš, J.; Štefančík, I. Changes in horizontal structure of natural beech forests on an altitudinal gradient in the Sudetes. Dendrobiology 2015, 73, 33-45. [CrossRef]

116. Vacek, Z.; Vacek, S.; Bulušek, D.; Podrázský, V.; Remeš, J.; Král, J.; Putalová, T. Effect of fungial pathogenes and climatic factors on production, biodiversity and health status of ash in mountain forests. Dendrobiology 2017, 77, 161-175. [CrossRef]

117. O'Callaghan, D.P.; Atkins, P.M.; Fairhurst, C.P. Behavioral responses of elm bark beetles to baited and unbaited elms killed by cacodylic acid. J. Chem. Ecol. 1984, 10, 1623-1634. [CrossRef] [PubMed]

118. Gibbs, J.N.; Brasier, C.M.; Webber, J.F. Dutch Elm Disease in Britain. In Forestry Commission Information Note 252; Forestry Commission Edinbourgh: Edinbourgh, UK, 1994.

119. Mina, M.; del Río, M.; Huber, M.O.; Thürig, E.; Rohner, B. The symmetry of competitive interactions in mixed Norway spruce, silver fir and European beech forests. J. Veg. Sci. 2018, 29, 775-787. [CrossRef]

120. Seidl, R.; Thom, D.; Kautz, M.; Martin-Benito, D.; Peltoniemi, M.; Vacchiano, G.; Wild, J.; Ascoli, D.; Petr, M.; Honkaniemi, J.; et al. Forest disturbances under climate change. Nat. Clim. Chang. 2017, 7, 395-402. [CrossRef]

121. Jandl, R. Climate-induced challenges of Norway spruce in Northern Austria. Trees For. People 2020, 1, 100008. [CrossRef]

122. Nothdurft, A.; Engel, M. Climate sensitivity and resistance under pure- and mixed-stand scenarios in Lower Austria evaluated with distributed lag models and penalized regression splines for tree-ring time series. Eur. J. For. Res. 2020, 139, 189-211. [CrossRef]

123. Forrester, D.I.; Kohnle, U.; Albrecht, A.T.; Bauhus, J. Complementarity in mixed-species stands of Abies alba and Picea abies varies with climate, site quality and stand density. For. Ecol. Manag. 2013, 304, 233-242. [CrossRef]

124. Block, J. Disposition rheinland-pfälzischer Waldbodensubstrate gegenüber Versauerung; Forest Damage, Soil and Water Conservation through Airborne Substances in Rhineland-Palatinate; Ministry of the Environment and Forest of Rhineland-Palatinate: Mainz, Germany, 1997.

125. Augusto, L.; Ranger, J.; Binkley, D.; Rothe, A. Impact of several common tree species of European temperate forests on soil fertility. Ann. For. Sci. 2002, 59, 233-253. [CrossRef] 
126. Forrester, D.I.; Albrecht, A.T. Light absorption and light-use efficiency in mixtures of Abies alba and Picea abies along a productivity gradient. For. Ecol. Manag. 2014, 328, 94-102. [CrossRef]

127. Huber, M.O.; Sterba, H.; Bernhard, L. Site conditions and definition of compositional proportion modify mixture effects in Picea abies-Abies alba stands. Can. J. For. Res. 2014, 44, 1281-1291. [CrossRef]

128. Hanewinkel, M.; Cullmann, D.A.; Schelhaas, M.J.; Nabuurs, G.J.; Zimmermann, N.E. Climate change may cause severe loss in the economic value of European forest land. Nat. Clim. Chang. 2013, 3, 203-207. [CrossRef]

129. Konôpková, A.; Kurjak, D.; Kmet', J.; Klumpp, R.; Longauer, R.; Ditmarová, L'; Gömöry, D. Differences in photochemistry and response to heat stress between silver fir (Abies alba Mill.) provenances. Trees Struct. Funct. 2018, 32, 73-86. [CrossRef]

130. Zimmermann, J.; Hauck, M.; Dulamsuren, C.; Leuschner, C. Climate Warming-Related Growth Decline Affects Fagus sylvatica, But Not Other Broad-Leaved Tree Species in Central European Mixed Forests. Ecosystems 2015, 18, 560-572. [CrossRef]

131. Lebourgeois, F.; Rathgeber, C.B.K.; Ulrich, E. Sensitivity of French temperate coniferous forests to climate variability and extreme events (Abies alba, Picea abies and Pinus sylvestris). J. Veg. Sci. 2010, 21, 364-376. [CrossRef]

132. Cavlovic, J.; Boncina, A.; Bozic, M.; Goršic, E.; Simončič, T.; Teslak, K. Depression and growth recovery of silver fir in uneven-aged Dinaric forests in Croatia from 1901 to 2001. Forestry 2014, 88, 586-598. [CrossRef]

133. Carrer, M.; Motta, R.; Nola, P. Significant Mean and Extreme Climate Sensitivity of Norway Spruce and Silver Fir at Mid-Elevation Mesic Sites in the Alps. PLoS ONE 2012, 7, e50755. [CrossRef]

134. Rötzer, T.; Biber, P.; Moser, A.; Schäfer, C.; Pretzsch, H. Stem and root diameter growth of European beech and Norway spruce under extreme drought. For. Ecol. Manag. 2017, 406, 184-195. [CrossRef]

135. Pretzsch, H.; Schütze, G.; Uhl, E. Resistance of European tree species to drought stress in mixed versus pure forests: Evidence of stress release by inter-specific facilitation. Plant Biol. 2013, 15, 438-495. [CrossRef]

136. Spinoni, J.; Naumann, G.; Vogt, J.V.; Barbosa, P. The biggest drought events in Europe from 1950 to 2012. J. Hydrol. Reg. Stud. 2015, 3, 509-524. [CrossRef]

137. Ols, C.; Bontemps, J.-D.; Gschwantner, T. Nadelbäume-Wie reagiert das Wachstum auf die Klimaerwärmung. BFW Prax. 2019, $50,30-34$.

138. Vitali, V.; Buntegen, U.; Bauhus, J. Seasonality matters-The effects of past and projected seasonal climate change on the growth of native and exotic conifer species in Central Europe. Dendrochronologia 2018, 48, 1-9. [CrossRef]

139. Gruber, A.; Zimmermann, J.; Wieser, G.; Oberhuber, W. Effects of climate variables on intra-annual stem radial increment in Pinus cembra (L.) along the alpine treeline ecotone. Ann. For. Sci. 2009, 66, 503. [CrossRef] [PubMed]

140. Swidrak, I.; Gruber, A.; Kofler, W.; Oberhuber, W. Effects of environmental conditions on onset of xylem growth in Pinus sylvestris under drought. Tree Physiol. 2011, 31, 1161-1171. [CrossRef] [PubMed]

141. Hänninen, H.; Tanino, K. Tree seasonality in a warming climate. Trends Plant Sci. 2011, 16, 412-416. [CrossRef] [PubMed]

142. Oberhuber, W.; Gruber, A.; Kofler, W.; Swidrak, I. Radial stem growth in response to microclimate and soil moisture in a drought-prone mixed coniferous forest at an inner Alpine site. Eur. J. For. Res. 2014, 133, 467-479. [CrossRef]

143. Ciceu, A.; Popa, I.; Leca, S.; Pitar, D.; Chivulescu, S.; Badea, O. Climate change effects on tree growth from Romanian forest monitoring Level II plots. Sci. Total Environ. 2020, 698, 134129. [CrossRef]

144. Versace, S.; Gianelle, D.; Garfi, V.; Battipaglia, G.; Lombardi, F.; Marchetti, M.; Tognetti, R. Interannual radial growth sensitivity to climatic variations and extreme events in mixed-species and pure forest stands of silver fir and European beech in the Italian Peninsula. Eur. J. For. Res. 2020, 139, 1-19. [CrossRef]

145. Klein, T. The variability of stomatal sensitivity to leaf water potential across tree species indicates a continuum between isohydric and anisohydric behaviours. Funct. Ecol. 2014, 28, 1313-1320. [CrossRef]

146. Roman, D.T.; Novick, K.A.; Brzostek, E.R.; Dragoni, D.; Rahman, F.; Phillips, R.P. The role of isohydric and anisohydric species in determining ecosystem-scale response to severe drought. Oecologia 2015, 179, 641-654. [CrossRef] [PubMed]

147. McDowell, N.G.; Allen, C.D. Darcy's law predicts widespread forest mortality under climate warming. Nat. Clim. Chang. 2015, 5, 669-672. [CrossRef]

148. Kolb, T.E.; Stone, J.E. Differences in leaf gas exchange and water relations among species and tree sizes in an Arizona pine-oak forest. Tree Physiol. 2000, 20, 1-12. [CrossRef] [PubMed]

149. Barbeta, A.; Ogaya, R.; Peñuelas, J. Dampening effects of long-term experimental drought on growth and mortality rates of a Holm oak forest. Glob. Chang. Biol. 2013, 19, 3133-3144. [CrossRef]

150. Teskey, R.; Wertin, T.; Bauweraerts, I.; Ameye, M.; McGuire, M.A.; Steppe, K. Responses of tree species to heat waves and extreme heat events. Plant Cell Environ. 2015, 38, 1699-1712. [CrossRef]

151. Hoffmann, N.; Schall, P.; Ammer, C.; Leder, B.; Vor, T. Drought sensitivity and stem growth variation of nine alien and native tree species on a productive forest site in Germany. Agric. For. Meteorol. 2018, 256-257, 431-444. [CrossRef]

152. O'Brien, M.J.; Leuzinger, S.; Philipson, C.D.; Tay, J.; Hector, A. Drought survival of tropical tree seedlings enhanced by nonstructural carbohydrate levels. Nat. Clim. Chang. 2014, 4, 710-714. [CrossRef]

153. Pretzsch, H.; Rötzer, T.; Matyssek, R.; Grams, T.E.E.; Häberle, K.H.; Pritsch, K.; Kerner, R.; Munch, J.C. Mixed Norway spruce (Picea abies [L.] Karst) and European beech (Fagus sylvatica [L.]) stands under drought: From reaction pattern to mechanism. Trees Struct. Funct. 2014, 28, 1305-1321. [CrossRef]

154. Rötzer, T.; Häberle, K.H.; Kallenbach, C.; Matyssek, R.; Schütze, G.; Pretzsch, H. Tree species and size drive water consumption of beech/spruce forests-A simulation study highlighting growth under water limitation. Plant Soil 2017, 418, 337-356. [CrossRef] 
155. Dănescu, A.; Albrecht, A.T.; Bauhus, J. Structural diversity promotes productivity of mixed, uneven-aged forests in southwestern Germany. Oecologia 2016, 182, 319-333. [CrossRef] [PubMed]

156. Gričar, J.; Čufar, K. Seasonal dynamics of phloem and xylem formation in silver fir and Norway spruce as affected by drought. Russ. J. Plant Physiol. 2008, 55, 538-543. [CrossRef]

157. Swidrak, I.; Gruber, A.; Oberhuber, W. Xylem and phloem phenology in co-occurring conifers exposed to drought. Trees Struct. Funct. 2014, 28, 1161-1171. [CrossRef] [PubMed]

158. Harrington, C.A.; Gould, P.J.; St.Clair, J.B. Modeling the effects of winter environment on dormancy release of Dougla-fir. For. Ecol. Manag. 2010, 259, 798-808. [CrossRef]

159. Rolland, C.; Michalet, R.; Desplanque, C.; Petetin, A.; Aimé, S. Ecological requirements of Abies alba in the French Alps derived from dendro-ecological analysisu. J. Veg. Sci. 1999, 10, 297-306. [CrossRef]

160. Mäkinen, H.; Nöjd, P.; Saranpää, P. Seasonal changes in stem radius and production of new tracheids in Norway spruce. Tree Physiol. 2003, 23, 959-968. [CrossRef] [PubMed]

161. van der Maaten, E. Climate sensitivity of radial growth in European beech (Fagus sylvatica L.) at different aspects in southwestern Germany. Trees 2012, 26, 777-788. [CrossRef]

162. Hathaway, D.H. The solar cycle. Living Rev. Sol. Phys. 2015, 12, 4. [CrossRef]

163. Šimůnek, V.; Vacek, Z.; Vacek, S.; Ripullone, F.; Hájek, V.; D’andrea, G. Tree rings of european beech (Fagus sylvatica L.) indicate the relationship with solar cycles during climate change in central and southern europe. Forests 2021, 12, 259. [CrossRef]

164. Kasatkina, E.A.; Shumilov, O.I.; Timonen, M. Solar activity imprints in tree ring-data from northwestern Russia. J. Atmos. Sol. Terr. Phys. 2019, 193, 105075. [CrossRef]

165. Matveev, S.M.; Chendev, Y.G.; Lupo, A.R.; Hubbart, J.A.; Timashchuk, D.A. Climatic Changes in the East-European Forest-Steppe and Effects on Scots Pine Productivity. Pure Appl. Geophys. 2017, 174, 427-443. [CrossRef]

166. McCracken, K.G.; Beer, J.; McDonald, F.B. A five-year variability in the modulation of the galactic cosmic radiation over epochs of low solar activity. Geophys. Res. Lett. 2002, 29, 3-6. [CrossRef]

167. Carl, G.; Doktor, D.; Koslowsky, D. Phase difference analysis of temperature and vegetation phenology for beech forest: A wavelet approach. Stoch. Environ. Res. Risk Assess. 2013, 5, 1221-1230. [CrossRef]

168. Tsiropoula, G. Signatures of solar activity variability in meteorological parameters. J. Atmos. Sol. Terr. Phys. 2003, 65, 469-482. [CrossRef]

169. Laurenz, L.; Lüdecke, H.J.; Lüning, S. Influence of solar activity changes on European rainfall. J. Atmos. Sol. Terr. Phys. 2019, 185, 29-42. [CrossRef]

170. Shumilov, O.I.; Kasatkina, E.A.; Mielikainen, K.; Timonen, M.; Kanatjev, A.G. Palaeovolcanos, solar activity and pine tree-rings from the Kola Peninsula (northwestern Russia) over the last 560 years. Int. J. Environ. Res. 2011, 5, 855-864. [CrossRef]

171. Dorotovič, I.; Louzada, J.L.; Rodrigues, J.C.; Karlovský, V. Impact of solar activity on the growth of pine trees: Case study. Eur. J. For. Res. 2014, 133, 639-648. [CrossRef]

172. Nagovitsyn, Y.A. Specific features in the effect of solar activity on the Earth's climate changes. Geomagn. Aeron. 2014, 54, 1010-1013. [CrossRef] 